\title{
Connexin Mediates Gap Junction-Independent Resistance to Cellular Injury
}

\author{
Jane H.-C. Lin, ${ }^{1}$ Jay Yang, ${ }^{3}$ Shujun Liu, ${ }^{2}$ Takahiro Takano, ${ }^{2}$ Xiaohai Wang, ${ }^{2}$ Qun Gao, ${ }^{2}$ Klaus Willecke, ${ }^{4}$ and \\ Maiken Nedergaard ${ }^{2}$ \\ Departments of ${ }^{1}$ Pathology and ${ }^{2}$ Anatomy and Cell Biology, New York Medical College, Valhalla, New York 10595, ${ }^{3}$ Department of Anesthesia, Columbia \\ University College of Physicians and Surgeons, New York, New York 10032, and ${ }^{4}$ Institut für Genetik, Abteilung Molekulargenetik, University of Bonn, \\ 53117 Bonn, Germany
}

\begin{abstract}
Although gap junctions regulate essential processes during development and differentiation, the role of gap junctions in cell death is poorly understood. We demonstrate here that the forced expression of connexin 43 (Cx43), the main constituent of astrocytic gap junctions, protected against cell injury with a potency that was comparable with that from the expression of the proto-oncogene $b c l 2$. The expression of two other members of the $\mathrm{Cx}$ family, $\mathrm{Cx} 32$ and $\mathrm{Cx} 40$, also increased the resistance to injury from exposures to calcium overload, oxidative stress, metabolic inhibition, tamoxifen, and UV irradiation, but not against staurosporine- and dexamethasonemediated death. Surprisingly, the anti-death activity of connexin proteins was independent of gap junction channel function, because physical isolation or the pharmacological inhibition of coupling did not significantly increase cell death. Moreover, cells expressing nonfunctional mutant connexins also acquired a high resistance to injury. These observations identify $\mathrm{Cx}$ proteins as active players in cell survival.
\end{abstract}

Key words: adhesion; C6 glioma; calcium homeostasis; hemichannels; cell morphology; purinergic receptors

\section{Introduction}

Gap junctions are a subset of membrane channels that link neighboring cells. They are composed of connexins (Cxs), a highly conserved multigene family (Bennett et al., 1994). At present, 20 $\mathrm{Cx}$ genes have been cloned and characterized from rodents, and homologs have been identified in humans, chicks, frogs, and fish (Evans and Martin, 2002). Gap junctions are ubiquitously expressed by cells of many types, and they are believed to play an essential role in diverse processes, including proliferation, differentiation, morphogenesis, and pattern formation (Kumar and Gilula, 1996; Goldberg et al., 2000; Grueterich et al., 2002; Huang et al., 2002; Levin, 2002).

In the brain, astrocytes are the chief expressers of gap junctions. During ischemic injury, astrocytes remain coupled until a very late stage of cell death (Cotrina et al., 1998a). Multiple roles have been ascribed to the persistence of coupling between dying and viable cells. First, the so-called kiss of death, whereby gap junctions facilitate the propagation and amplification of cell injury (Lin et al., 1998), increases neuronal vulnerability to ischemic (Rami et al., 2001) and traumatic injury (Frantseva et al., 2002). Similarly, ganciclovir gene therapy relies on gap junctions to conduct the bystander killing (Mesnil et al., 1996; Carystinos et al., 1999; Andrade-Rozental et al., 2000; Krutovskikh et al., 2002). Second, the so-called Good Samaritan effects, whereby gap junctions serve to stabilize cellular calcium homeostasis and dissipate

Received Aug. 1, 2002; revised 0ct. 2, 2002; accepted 0ct. 10, 2002.

This work was supported by American Heart Association Grant 99-50994T (J.H.-C.L.), by National Institute of Neurological Disorders and Stroke/National Institutes of Health Grants NS30007 and NS38073 (M.N.), and by the German Research Association (K.W.). We thank Earl Bueno for excellent technical assistance.

Correspondence should be addressed to Dr. Jane Lin, Department of Pathology, Basic Science Building, New York Medical College, Valhalla, NY 10595. E-mail:jane_lin@nymc.edu.

Copyright $\odot 2002$ Society for Neuroscience $\quad 0270-6474 / 02 / 220430-12 \$ 15.00 / 0$ oxidative stress, decrease neuronal vulnerability to oxidative stress (Blanc et al., 1998).

In general, the effects of $\mathrm{Cx}$ expression have been attributed to gap junction coupling and sharing of a common pool of intracellular messengers. However, Cxs play multiple roles other than being an integral constituent of gap junction channels. For example, Cx expression facilitates the release of ATP and oxidized nicotinamide adenine dinucleotide independently of gap junction coupling (Cotrina et al., 1998b; Bruzzone et al., 2001; Arcuino et al., 2002); several lines of work suggest that Cxs regulate cell growth by mechanisms that do not require gap junction communication (Huang et al., 1998; Omori and Yamasaki, 1998; Moorby and Patel, 2001; Qin et al., 2002).

In this study, we set out to define the role of gap junction channels versus other effects of Cx expression in cell injury. We used an array of wild types as well as mutated Cxs with defects in channel function to analyze the role of Cx expression in cellular resistance. We found that Cx expression very significantly enhanced injury resistance, an in vitro finding that echoes the results of the in vivo study by Oguro et al. (2001) that Cx32 contributes to the survival and resistance of GABAergic interneurons in the hippocampus during global ischemia. Three members of the $\mathrm{Cx}$ family increased the injury thresholds required to activate the classical pathways of both apoptotic and necrotic cell death. Mechanistic analyses revealed that functional gap junction channels played a minor role in injury protection. Rather, the increased resistance was attributed to $\mathrm{Cx}$-mediated cytoskeletal organization and faster normalization of cytotoxic elevations of calcium, which enabled Cx-expressing cells to survive an otherwise lethal injury.

These studies conclude that $\mathrm{Cx}$ expression has a very significant impact on cellular injury resistance by processes indepen- 
dent of gap junction coupling. The fact that $\mathrm{Cx}$-mediated injury resistance does not require functional gap junction channels provides a platform for separating the advantage of $\mathrm{Cx}$ expression from the harmful effects of bystander death.

\section{Materials and Methods}

Cell cultures, stable transfection, and adenovirus-mediated gene transfer. C6 glioma, HeLa (American Type Culture Collection, Manassas, VA), and N2A (a clone with no electrophysiological detectable gap junction coupling; a gift from D. C. Spray, Albert Einstein College, Bronx, NY) were grown in DMEM supplemented with $10 \%$ fetal bovine serum and antibiotics. cDNA for human Bcl2 (a gift from S. Korsmeyer, Harvard Medical School, Boston, MA) was cloned in pCEP4 (Invitrogen, Carlsbad, CA), and its expression driven by a cytomegalovirus promoter. Transfection was performed with Clonfectin (Clontech, Palo Alto, CA) according to the manufacturer's instructions; stable transfectants were selected with $200 \mathrm{U} / \mathrm{ml}$ hygromycin. Independent clones were established. Parallel control transfectants were obtained simultaneously using the expression vector without the cDNA insert. The expression of $\mathrm{Bcl} 2$ was evaluated by Northern blot analysis, immunostaining (anti-Bcl2; Oncogene Sciences, Cambridge, MA) and resistance to calcium overload, oxidative stress, and metabolic inhibition. Control transfectants, like their parental C6, expressed no detectable Bcl2. Likewise, native C6 glioma expresses little $\mathrm{Cx} 43$. Control transfected clones with no detectable Cx43 immunoreactivity, and which exhibited no functional coupling by dye-transfer assays, were used in this study as a control (C6-mock 1-4 cells). cDNA for $\mathrm{Cx} 43$ was ligated into the expression vector pcDNA1, and cDNAs for $\mathrm{Cx} 40$ and $\mathrm{Cx} 32$ were ligated into pBEHpac18. Transfections were performed as described above, and stable transfectants were selected with $2 \mathrm{mg} / \mathrm{ml}$ geneticin (for $\mathrm{Cx} 43$ ) or $2 \mu \mathrm{g} / \mathrm{ml}$ puromycin (for $\mathrm{Cx} 32$ and $\mathrm{Cx} 40)$. The chimeric constructs $\mathrm{Cx} 40^{\star} 43 \mathrm{C} 3$ and $\mathrm{Cx} 40^{\star} 43 \mathrm{E} 2$ were generated by exchanging $\mathrm{Cx} 40$ domains [ $\mathrm{C} 3$ is the third cytoplasmic domain (i.e., the C-terminal tail) and E2 is the second extracellular loop] for the corresponding domains of $\mathrm{Cx} 43$ by site-directed mutagenesis (Haubrich et al., 1996). The Cx43M1 point mutation (C61S) was generated by site-directed mutagenesis, replacing the cysteine residue in position 61 with a serine residue. All of these cDNA constructs were ligated to the expression vector pBEHpac18 (Lin et al., 2002). The expression of $\mathrm{Cx} 43, \mathrm{Cx} 40$, and $\mathrm{Cx} 32$ was determined by immunolabeling; they were related to gap junction coupling by functional dye transfer on a biweekly schedule.

Fusion cDNA of enhanced green fluorescent protein (EGFP; Clontech) and one of the two mutant $\mathrm{Cx} 43$ constructs was generated by the PCR overlap extension method (Ho et al., 1989): dominant-negative mutants L160M (residue 160 at the third transmembrane domain, where lysine is replaced with methionine) (Omori and Yamasaki, 1998; Goldberg et al., 2000) and $\Delta 130-137$ (residues $130-137$ at the second cytoplasmic domain were deleted) (Krutovskikh et al., 2002; Oyamada et al., 2002). The fusion cDNAs were subcloned into the Rous sarcoma virusdriven expression cassette of the pAdlox vector containing the adenovirus type $5^{\prime}$ left long terminal repeat and $\Psi 5$ packaging sequence followed by a $\operatorname{lox} P$ sequence at the $3^{\prime}$ end (Hardy et al., 1997). The resultant constructs (e.g., Cx43L160M-EGFP-pAdlox) were each linearized and coinfected into a Cre-recombinase-expressing stable human embryonic kidney 293 cell line along with the $\Psi 5$ DNA, generating an infective but replication-deficient adenovirus [e.g., Ad(Cx43L160M-EGFP)]. These fusion proteins expressed as green fluorescent plaques at cell-to-cell contact (see Fig. 5A). A viral construct for wild-type $\mathrm{Cx} 43$ was generated in the same way, except that cDNAs for $\mathrm{Cx} 43$ and EGFP were carried on separate cassettes. EGFP expressed throughout cytoplasm, whereas Cx43 expression needed to be visualized via immunocytochemistry (see Fig. 6, inset).

For killing studies, viruses were added to dissociated N2A, HeLa, or wild-type C6 cells at $\sim 300$ pfu per cell during seeding. Viral expression was monitored by confocal microscopy of EGFP. Peak expression ( $>98 \%$ efficiency) usually occurred at $\sim 48 \mathrm{hr}$, at which time cells were exposed to various concentrations of tamoxifen. The cell survival rate was evaluated $24 \mathrm{hr}$ later by Alamar Blue assay (Biosource, Camarillo, CA) (Farinelli and Greene, 1996).
Of note, the Cx- as well as the mock-transfected clones selected for this study all exhibited a proliferation rate that did not differ significantly from C6 wild type. Typically, the clones doubled in cell number every 26-28 hr (data not shown).

Mice with a null-mutation of Cx43. Heterozygotes of the Cx43 knockout $(\mathrm{KO})$ line were obtained from The Jackson Laboratory (Bar Harbor, $\mathrm{ME}$ ). Pregnant females were killed at $18-20 \mathrm{~d}$ of gestation, and the embryonic brains were cultured as described previously (Nedergaard, 1994; Cotrina et al., 1998a). To identify Cx43 null homozygotes, heterozygotes, and wild types, PCR for amplifying tail-blood genomic DNA flanking the null deletion was used, as per The Jackson Laboratory protocol. Also, immunohistochemical mapping of the extent of $\mathrm{Cx} 43$ expression was performed in conjunction with dye-transfer assays. Astrocytes from the Cx43 null homozygote and wild-type mice used in this study were from three different litters. Cultures were grown 2-6 weeks in vitro before use.

Immunocytochemistry and functional coupling assay. Astrocytes and C6 cells were plated on $12 \mathrm{~mm}$ uncoated coverslips $\left(2-4 \times 10^{4}\right.$ cells $)$, grown in 24 well plates to near confluence, and fixed with $4 \%$ paraformaldehyde. Cultures were permeabilized with $0.1 \%$ Triton X-100, blocked with $10 \%$ normal goat serum (Cotrina et al., 1998a), and immunoreacted with one of the following: polyclonal antibodies directed against amino acid residues 302-319 of the C-terminal tail of Cx43 (Bruce Nicholson, State University of New York, Buffalo, NY) (De Sousa et al., 1997), polyclonal antibodies directed against residues 337-358 of the C-terminal tail of Cx40 (Otto Traub, Universität Bonn, Bonn, Germany) (Traub et al., 1994), and monoclonal antibodies against residues 95-125 in the central cytoplasmic loop of Cx32 (David Paul, Harvard University, Boston, MA) (Meda et al., 1993).

The dye-transfer technique was adapted from Goldberg et al. (1995). Cells were loaded with 5 (and 6)-carboxy- $2^{\prime}, 7^{\prime}$-dichlorofluorescein diacetate (CDCF diacetate; Molecular Probes, Eugene, OR) for $5 \mathrm{~min}$, washed, and trypsinized. After resuspension, the cells were labeled with $10 \mu \mathrm{M}$ 1,1'-dioctadecyl-3,3,3',3'-[tetramethylindocarbocyanine perchlorate $\left(\mathrm{DiIC}_{18}\right)$ (Molecular Probes) for $10 \mathrm{~min}$ and mixed with unlabeled cells at a 1:250 ratio. One hour after plating on polylysine-coated dishes, dye transfer from the $\mathrm{CDCF} / \mathrm{DiIC}_{18}$-labeled (donor) cells to unlabeled (recipient) cells was evaluated using confocal scanning microscopy. Counts of both the labeled donor cells and their recipients were performed manually. The coupling index was defined as the fraction of donor cells that transferred dye to surrounding cells, multiplied by the mean number of receiving cells.

Cell killing. Seven different paradigms of cell killing were studied. (1) Exposure to the calcium ionophore lasalocid (Lin et al., 1998) $(40 \mu \mathrm{M}$ lasalocid for 20-90 $\mathrm{min}$ ); (2) oxidative stress, as induced by the free radical generator menadione (200 $\mu \mathrm{M}$ for $10-35 \mathrm{~min}$ ) (Zhong et al., 1993); (3) metabolic inhibition, accomplished using a combination of 1 mM KCN (an electron transport inhibitor) and $0.02 \mathrm{~mm}$ iodoacetate (a blocker of glycolysis) for $2-8 \mathrm{hr}$ (Cotrina et al., 1998a); (4) tamoxifen (10-25 $\mu \mathrm{M}$ for $24 \mathrm{hr}$ ) (Zhang et al., 2000); (5) dexamethasone $(0.1-5 \mathrm{mM}$ for $24 \mathrm{hr}$ ) (Simard et al., 1999); (6) UV exposure (30 W, $15 \mathrm{~cm}$ for $10-50$ min) (Billecke et al., 2002; Zeng et al., 2002); and (7) staurosporine (0-3 $\mu \mathrm{M}$ ) (Kabir et al., 2002; Rabkin and Kong, 2002). In each run, six cultures were included at a minimum: one set as a control and the remaining five to adjust exposure duration (e.g., 10, 12, 14, 16, and 18 min of menadione treatment) or concentrations, to generate a dose-response curve. Cultures were confluent $1 \mathrm{~d}$ after seeding. Exposures to the first three insults were performed in $\mathrm{HBSS}$ at $37^{\circ} \mathrm{C}$. The cultures were washed before and after with HBSS and returned to the incubator in fresh serum-free DMEM/F12 medium. Control cultures were exposed to HBSS and processed identically. Twenty-four hours later, the viability was assessed either by quantifying the number of apoptotic cells [Hoechst $(2 \mu \mathrm{M})$ or terminal deoxynucleotidyl transferase-mediated biotinylated UTP nick end labeling (TUNEL) stain (Lin et al., 1998)] or by alamar blue assay (Biosource) (Farinelli and Greene, 1996). Each data point represented the average of at least five different runs (range, 5-177).

Cell labeling and calcium imaging. In cocultures, C6-Cx43 cells were prelabeled with a $2 \mu \mathrm{M}$ concentration of the red fluorescent cell tracker dye 5-(and-6)-(((4-chloromethyl)benzoyl)-amino)tetramethylrhodamine (CMTMR) (Molecular Probes), according to the manufacturer's instruc- 
tions. CMTMR contains a thiol-reactive chloromethyl group that, after reaction with intracellular thiols, becomes membrane- and gap junction-impermeable; the labeling does not alter the sensitivity to injury (Lin et al., 1998). The mixed cultures were loaded with $5 \mu \mathrm{M}$ fura- $2 \mathrm{AM}$ for $1 \mathrm{hr}$. Cytosolic $\mathrm{Ca}^{2+}$ levels were quantified using Image-1 software (Universal Imaging Corporation, West Chester, PA) and an SIT camera (Dage-MTI, Michigan City, IN) as described previously (Lin et al., 1998).

\section{Results}

Exogenous expression of $\mathrm{Cx} 43$ increases the resistance of $\mathrm{C} 6$ cells to injury

The C6 glioma cell line was originally cloned from a rat glial tumor induced by $N$-nitrosomethylurea (Benda et al., 1968). Wild-type C6 cells are poorly coupled and display very low levels of transfer of gap junction-permeable dyes (Cotrina et al., 2000). C6 cells have been extensively used as a model of astrocytes, because the expression of many receptor types, ion channels, and transport systems mimics that of astrocytes (Brismar, 1995). To study the role of gap junctions in cellular responses to injury, we have established 10 stable clones of C6 cells expressing the predominant astrocytic gap junction protein connexin 43 (C6Cx43) (Lin et al., 1998). The data presented here were from four representative clones compared with four mock-transfected clones. The expression of $\mathrm{Cx} 43$ was associated with a significant increase in intercellular coupling. A gap junction-permeable dye, CDCF, was transferred to a mean of $0.8 \pm 0.2$ and $7.0 \pm 0.07$ C6-mock 1 versus C6-Cx43 cells, respectively $(p<0.001)$. The expression of $\mathrm{Cx} 43$ was associated with a substantial increase in the cellular resistance to injury. Control C6 cells are highly sensitive to injury, and most cells died uniformly if exposed for $>25$ min to the calcium ionophore lasalocid $(40 \mu \mathrm{M})$. Half-maximal death occurred after $12 \pm 5 \mathrm{~min}\left(\mathrm{LD}_{50}\right.$, in the range of $10-25$ min) of C6-mock 1 cell exposure to ionophore, but after $47 \pm 6$ $\mathrm{min}$ (in the range of 40-65 $\mathrm{min}$ ) for $\mathrm{C} 6-\mathrm{Cx} 43$ cells (Fig. 1). In comparison, the stable expression of $\mathrm{Bcl} 2(\mathrm{C} 6-\mathrm{Bcl} 2)$ increased the $\mathrm{LD}_{50}$ to $42 \pm 7 \mathrm{~min}$, as reported previously (Lin et al., 1998). Thus, Cx43 expression provided the same extent of protection against calcium ionophore-induced injury as $b c l 2$, a protooncogene widely studied for its anti-apoptotic action (Fig. 1).

\section{Three different members of the connexin family possess the anti-death activity}

To determine whether anti-death activity is restricted to $\mathrm{Cx} 43$, or alternatively, is a more general feature of gap junction coupling, we generated C6 clones that stably expressed Cx32 (C6-Cx32). Cx32 is not endogenously expressed by C6 glioma or astrocytes, but it is the prominent gap junction protein among Schwann cells (Abrams et al., 2002). Seven of the C6-Cx32 clones displayed extensive dye coupling and transferred CDCF to an average of $11 \pm 1$ neighboring cells. C6-Cx32 cells were also highly resistant to ionophore, with an $\mathrm{LD}_{50}$ of $55 \pm 6 \mathrm{~min}$ (Fig. 2). The expression of connexin 40 (C6-Cx40) also increased coupling and ionophore resistance in parallel. In comparison, the $\mathrm{LD}_{50}$ values of four mock-transfected clones with low coupling were in the range of $12-16 \mathrm{~min}$ (Fig. 2). Plotting $\mathrm{LD}_{50}$ as a function of the coupling index (Fig. $2 B$, inset) showed that injury resistance was a linear function of the coupling index $(r=0.97)$. Collectively, these observations indicate that several different Cx proteins robustly protect against ionophore-induced injury.

\section{Connexin expression increases resistance to a variety of injury paradigms}

Transient exposure to the calcium ionophore lasalocid triggers a cell-death process that in its time course and progression shares

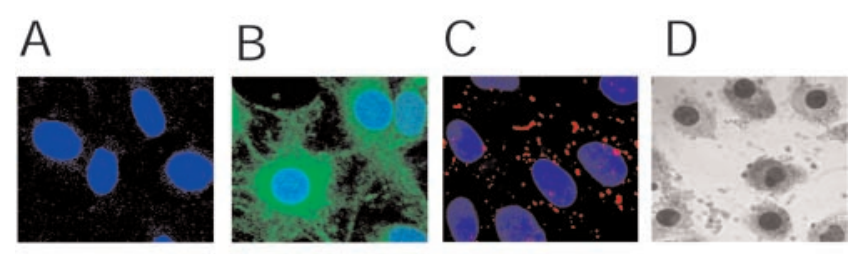

E

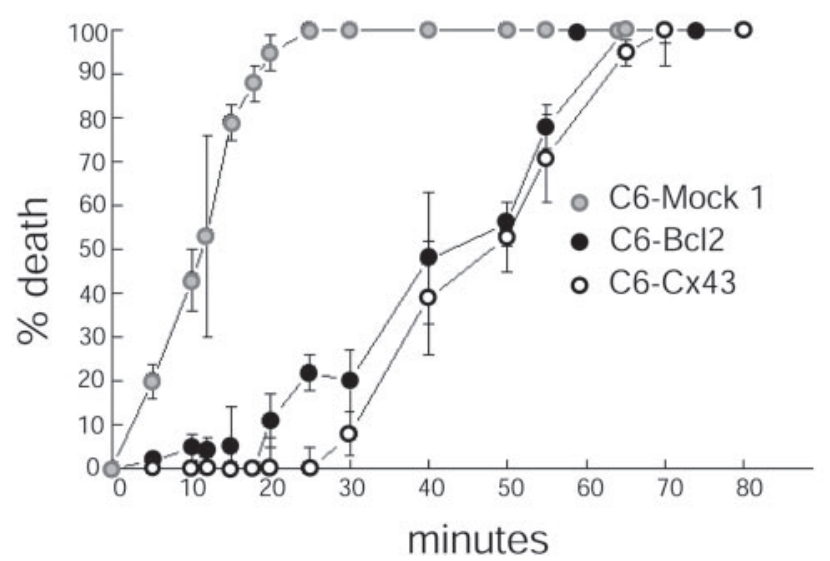

Figure 1. Cx43 expression confers resistance to injury. $A-C$, Confocal microscopic images showing double-immunofluorescence labeling for $\mathrm{BCl} 2$ (fluorescein-tagged secondary antibody) and (x43 (Texas Red-tagged secondary antibody). The nuclei were counterstained with Hoechst (blue). A, C6-mock 1 cells express undetectable levels of either $(x 43$ or $B c 12$. B, C 6 cells stably expressing $\mathrm{BCl} 2$ ( $C 6-\mathrm{BCl} 2$ cells) are strongly immunoreactive. $C, C \times 43$ immunoreactive plaques in C 6 cells stably expressing $\mathrm{Cx} 43$ ( $66-C \times 43$ cells). Scale bar, $10 \mu \mathrm{m}$. D, TUNEL-positive C6-mock 1 cells fixed $24 \mathrm{hr}$ after a 10 min exposure to the calcium ionophore lasalocid ( $40 \mu \mathrm{m})$. $E$, Percentage of cell death as a function of exposure time to lasalocid $(40 \mu \mathrm{m})$ in $(6-$ mock 1 , $\mathrm{C} 6-\mathrm{C} \times 43$, and $\mathrm{C} 6-\mathrm{BCl} 2$ cells. $\mathrm{C} 43$ expression and $\mathrm{BC} 2$ expression are both associated with a substantial increase in cellular resistance to the calcium ionophore. Error bars indicate SEM.

many features with necrosis. Similar patterns of cell death can be evoked by exposure to the producer of free radicals, menadione, or by "chemical ischemia," combined treatment with KCN and iodoacetate. We found here that expression of $\mathrm{Cx} 43, \mathrm{Cx} 32$, and $\mathrm{Cx} 40$ was associated with a substantial increase in resistance to menadione and KCN/iodoacetate exposure (Fig. 3). Likewise, the proto-oncogene $\mathrm{Bcl} 2$ also afforded protection against both of these insults in accordance with previous reports (Zhong et al., 1993; Kane et al., 1995; Myers et al., 1995). Several injury paradigms commonly used in the study of apoptotic injury, including UV irradiation, tamoxifen, staurosporine, and dexamethasone, were studied next. Cx43 expression robustly protected against tamoxifen and UV irradiation but not against dexamethasoneand staurosporine-induced injury. Both C6-mock and Cxexpressing cells died if exposed to dexamethasone at a concentration of $>3 \mathrm{~mm}$. Likewise, staurosporine killed all cell types at concentrations of $>2 \mu \mathrm{M}$. Together, these observations indicate that gap junction-coupled cells display high resistance to most but not all types of cellular stress. A similar observation was made that $\mathrm{Bcl} 2$ does not protect against several injury paradigms (Takayama et al., 1995; Reed et al., 1996). We compared gap junction coupling during the process of tamoxifen- and dexamethasone-induced cell death. Tamoxifen $(20 \mu \mathrm{M})$ and dexamethasone $(2.5 \mathrm{~mm})$ both reduced coupling (15.2 \pm 3 vs $22.1 \pm 0.6 \%$ of vehicle-treated control cultures, respectively). Thus, both injury paradigms decreased but did not abolish gap junction coupling during the active process of cell death. Because $\mathrm{Cx} 43$ expression afforded protection against tamoxifen-induced 

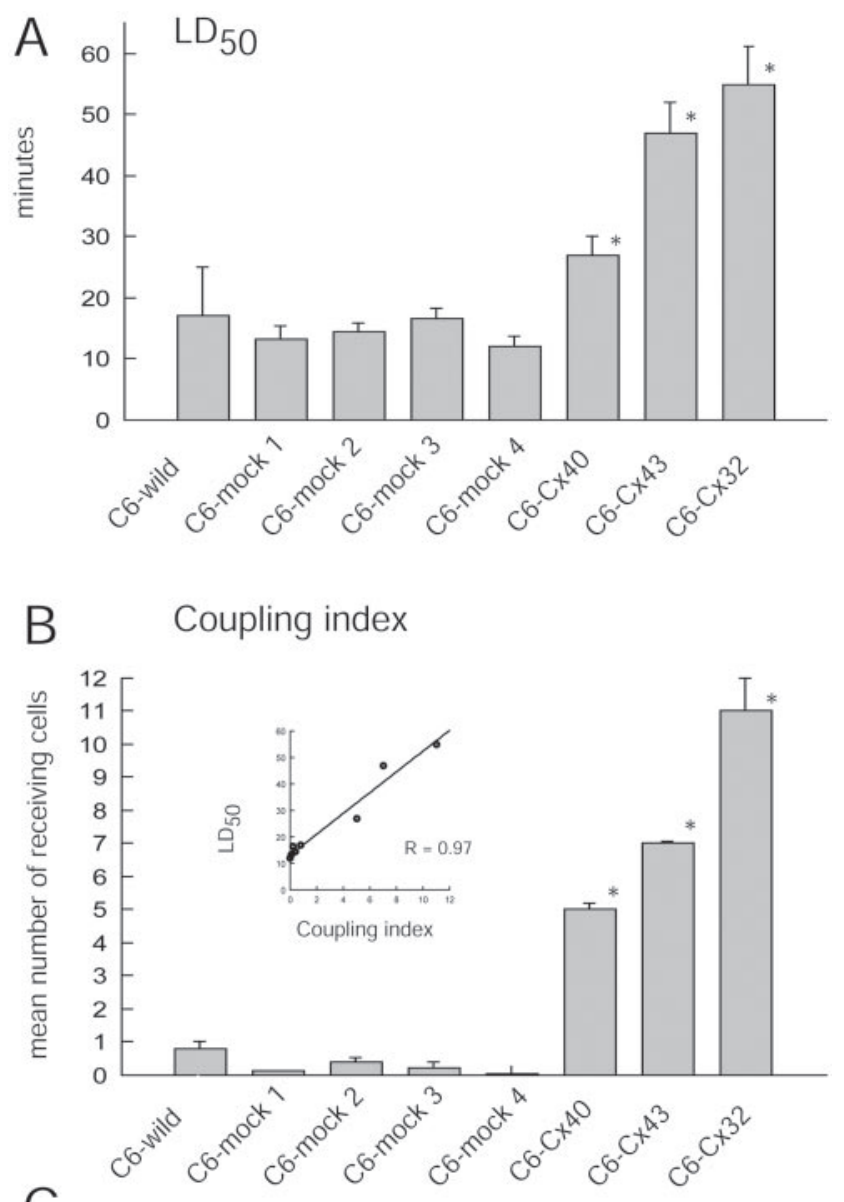

C

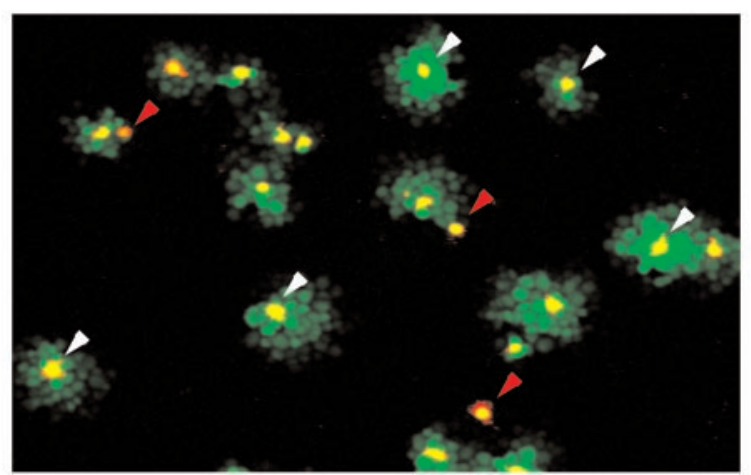

Figure 2. Anti-death activity in $\mathrm{C} x 43-, \mathrm{C} \times 40$-, and $\mathrm{C} \times 32$-expressing clones. $A, \mathrm{LD}_{50}$ (dosage causing half-maximal death) for the calcium ionophore lasalocid $(40 \mu \mathrm{M})$ is significantly higher for $\mathrm{Cx} 43, \mathrm{C} \times 40$, and $\mathrm{Cx} 32$ cells than for four mock-transfected sister clones, C6-mock 1, C6mock 2, (6-mock 3 , and (6-mock 4. ${ }^{*} p<0.01$. Error bars indicate SEM. B, Coupling index in the same clones as in $A$. Inset, $\mathrm{LD}_{50}$ is a direct function of the coupling index $(r=0.97) .{ }^{*} p<$ 0.01; ANOVA and post hoc Bonferroni $t$ test. Error bars indicate SEM. C, An example of the dye-transfer assay. $\mathrm{C}_{6-\mathrm{C}} 43$ cells were preloaded with DilC ${ }_{18}$ (red) and the gap junctionpermeable tracer CDCF ( green). Labeled C6 - Xx43 cells were cocultured with unlabeled C6 Cx43 cells for $1 \mathrm{hr}$; gap junctional coupling was quantified by the transfer of $\mathrm{CDCF}$ from Dil $\mathrm{C}_{18^{-}}$ labeled cells to unlabeled cells. Donor cells appear yellow because of the merge of red and green labeling. Clusters of green receiving cells surround yellow donors when the donor cell establishes a gap junction with adjacent cells (white arrowheads), whereas single yellow-red cells represent donor cells that fail to establish gap junctions (red arrowheads). The coupling index is defined as the mean number of receiving ( green) cells per donor ( yellow) cell.

injury but not against dexamethasone-induced injury, the extent of coupling during the process of cell death may not be a significant factor in $\mathrm{Cx}$-mediated injury resistance.

Of note, the level of Cx expression appeared to be an impor-
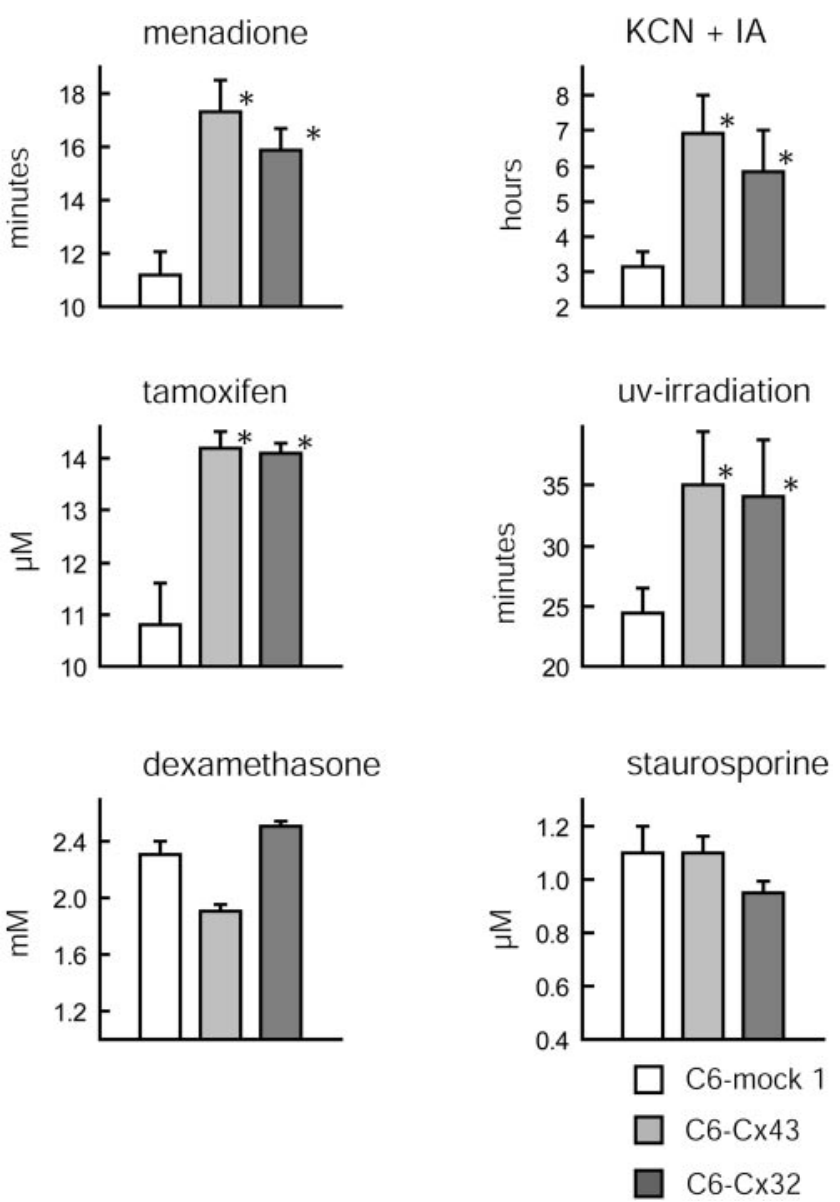

Figure 3. $C \times 43$ and $C \times 32$ confer resistance to several but not all injury paradigms. The $L_{50}$ of C6-mock 1, C6-Cx43, and C6-Cx32 cells exposed to menadione (200 $\mu \mathrm{M}), \mathrm{KCN}(1 \mathrm{~mm})$ and iodoacetate $(I A ; 0.02 \mathrm{~mm})$, tamoxifen $(10-25 \mu \mathrm{M})$, UV irradiation ( $0-60 \mathrm{~min})$, dexamethasone $(0-6 \mathrm{mM})$, and staurosporine $(0-3 \mu \mathrm{m})$ is shown. The expression of $\mathrm{C} \times 43$ and $\mathrm{C} \times 32$ protects $\mathrm{C} 6$ cells against menadione, $K C N$ and $I A$, tamoxifen, and UV irradiation but not against dexamethasone and staurosporine. ${ }^{*} p<0.01$; ANOVA and post hoc Bonferroni $t$ test. Error bars indicate SEM.

tant determinant of injury resistance. We compared several clones with low $\mathrm{Cx} 32$ expression (coupling indices in the range of 2-4) with C6-Cx32 with high expression (coupling indices in the range of $8-13$ ). High expressers of $\mathrm{Cx} 32$ were consistently more resistant to injury evoked by calcium ionophore, ATP depletion, and menadione exposure, compared with low-expressing clones. Figure $4 A-C$ illustrates results from studies of the mock 1 control versus one representative clone of each of the two expression levels. In addition, C6-Cx43 retained the transfected cDNA well. Repeated passaging did not diminish either the level of Cx43 expression or the corresponding injury resistance (Fig. 4D).

Approaching from the opposite direction, we tested the effect of two dominant-negative Cx43 mutants, L160M and $\Delta 130-137$, on injury resistance. We chose C6 wild-type cells because these cells display a low level of $\mathrm{Cx} 43$ expression and a minor degree of coupling (Fig. 2) (Cotrina et al., 2000). As shown in Figure 5A, these dominant-negative $\mathrm{Cx} 43$ proteins succeeded in trafficking to the cell-to-cell junction and exerted their inhibitory actions, resulting in a significant increase in the sensitivity of their host cells to tamoxifen. Resistance of both L160M- and $\Delta 130-137$ expressing cultures was significantly increased compared with EGFP-expressing sister cells (Fig. 5B). Thus, interference of Cx43 functions increased tamoxifen sensitivity, which is consistent 

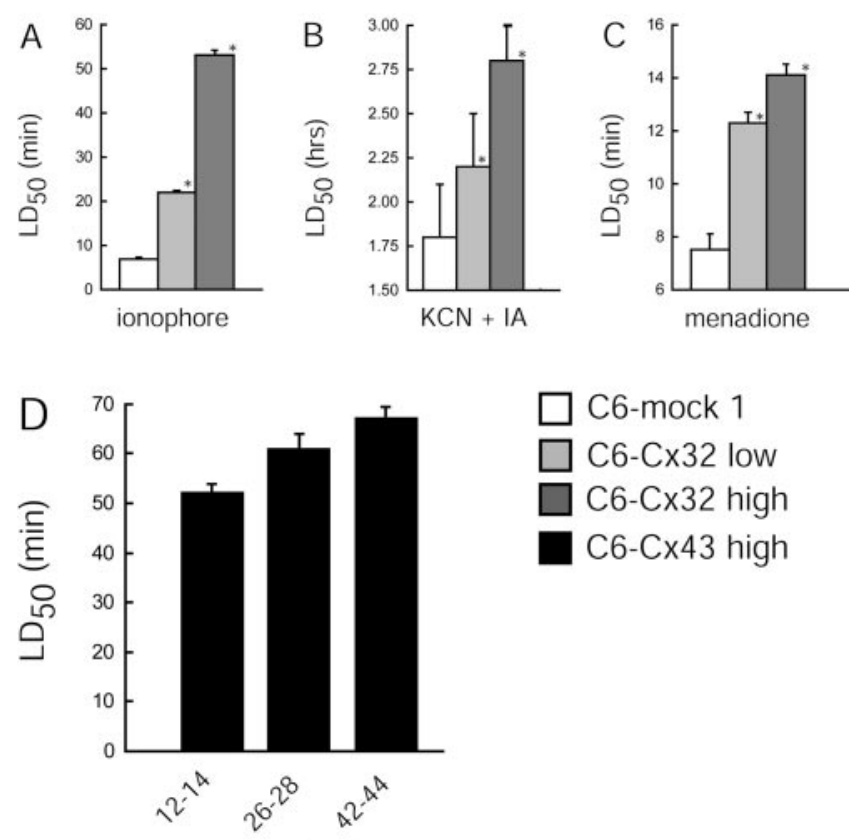

number of replates

Figure 4. Anti-death activity is highest in cells with high (x expression and is not affected by multiple replating. Comparison of injury resistance of $(6$-mock 1 cells (coupling index, 0.2$)$, a low (x32-expressing clone (coupling index, $2.3 \pm 0.5)$, and a high (x32-expressing clone (coupling index, $11 \pm 1)$. Resistance to various insults is expressed as $\mathrm{LD}_{50}$ for lasalocid $(40 \mu \mathrm{M})$ $(A)$, menadione $(200 \mu \mathrm{M})(C)$, and $\mathrm{KCN}(1 \mathrm{~mm})$ and iodoacetate $(0.02 \mathrm{~mm})(B)$. The highexpression clone is consistently more resistant than the low-expression clone. ${ }^{*} p<0.01$; ANOVA and post hoc Bonferroni $t$ test compared with C 6 -mock 1 cells. D, Multiple replating of $\mathrm{C} 6-\mathrm{CX} 43$ cells does not decrease the $\mathrm{LD}_{50}$ of lasalocid. Error bars indicate SEM.

with the idea that $\mathrm{Cx}$ expression positively regulates cellular resistance.

Connexin expression also increases the resistance of N2A and HeLa cells to injury

Interestingly, the anti-death activity of $\mathrm{Cx} 43$ was not restricted to C6 glioma cells. Treatment of N2A neuroblastoma cells with $\mathrm{Ad}(\mathrm{Cx} 43-\mathrm{EGFP})$ increased the level of resistance to tamoxifen relative to controls that were treated with $\mathrm{Ad}(\mathrm{EGFP})$ (Fig. 6). Both Cx43 and GFP expression (Fig. 6, inset) and the protection persisted for at least three additional passages. HeLa cells, a human-derived cervical tumor cell line with low endogenous $\mathrm{Cx}$ expression (Elfgang et al., 1995), also displayed a significant increase in cellular resistance to tamoxifen after the AdCx43-EGFP treatment. Control Ad(EGFP)-HeLa cells died uniformly if exposed to $>22.5 \mu \mathrm{M}$ tamoxifen, whereas AdCx43-EGFPtransfected sister cells tolerated $30 \mu \mathrm{M}$ tamoxifen without a sign of cellular deterioration. In all, these data support the idea that $\mathrm{Cx}$ expression protects against cell injury in a variety of cell lines.

Gap junction function is not required for connexin-mediated injury resistance

We subsequently assessed the effect of nonfunctional Cx mutations on cell resistance. Exchanging the cysteine residue of position 61 of the Cx43 sequence with serine by site-directed mutagenesis results in the loss of functional channel formation in cell lines expressing the mutant connexins (Elfgang et al., 1995; Haubrich et al., 1996; Lin et al., 2002). Three high-expressing clones were selected for the killing study. Despite a high level of C61S-Cx43 expression, Cx43 immunoreactive plaques were not
A
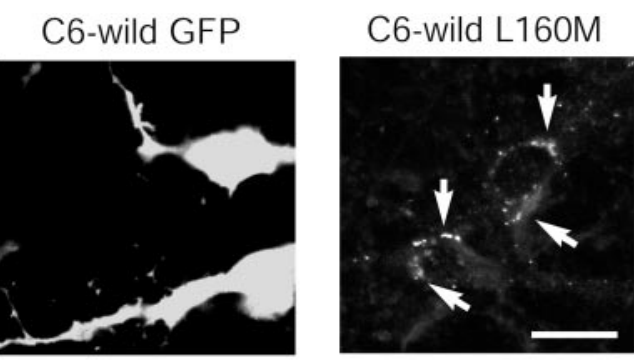

B

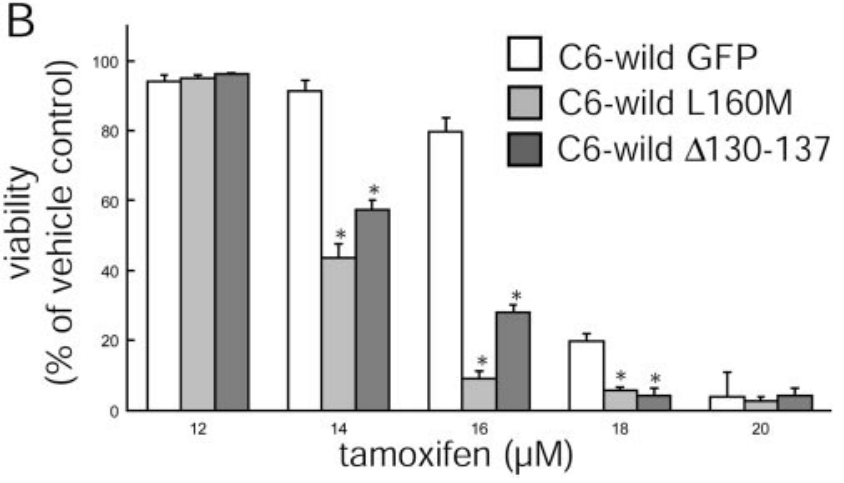

Figure 5. Dominant-negative Cx43 mutants reduce the resistance of wild-type C 6 cells. $A$, The expression of the mutant $\mathrm{Cx} 43 \mathrm{~L} 160 \mathrm{M}$ as plaques at cell-to-cell contact was visualized via the fluorescence of EGFP (white arrows), whereas (6 wild type transfected with $\mathrm{Ad}(\mathrm{EGFP})$ displays diffuse fluorescence. Scale bar, $10 \mu \mathrm{m}$. B, C6 wild-type cells endogenously express a low level of $C x 43$, and their resistance to tamoxifen is significantly reduced after the expression of the CX43 dominant-negative mutants L160M and $\Delta 130-137$ compared with cultures of C6 wild type expressing EGFP only. ${ }^{*} p<0.01$; ANOVA and post hoc Bonferroni $t$ test. Error bars indicate SEM.

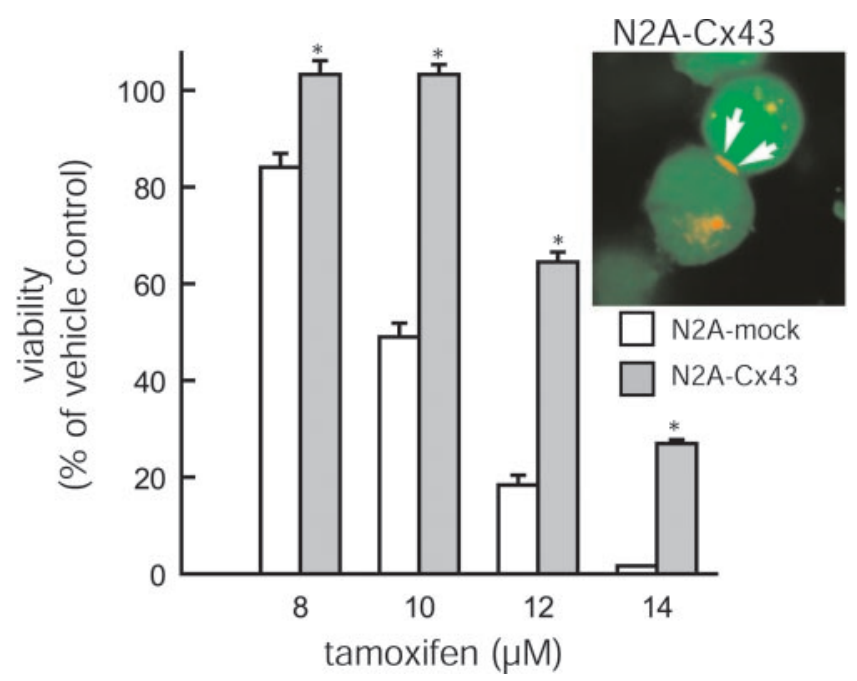

Figure 6. Resistance of N2A neuroblastoma cells to tamoxifen is increased with Cx43 expression. Cellular resistance to tamoxifen is increased in N2A cells transfected with an adenoviral construct, $\mathrm{Ad}(\mathrm{Cx} 43-\mathrm{EGFP})$, relative to mock controls that have been transfected with $\mathrm{Ad}(\mathrm{EGFP})$. ${ }^{*} p<0.01$; ANOVA and post hoc Bonferroni $t$ test. Error bars indicate SEM. Inset, Expression of Cx43 was visualized via immunocytochemistry with Cy3-tetramethylrhodamine isothiocyanate-tagged secondary antibodies. Because CDNAs for Cx43 and EGFP are located on separate cassettes, EGFP fluorescence is diffuse, whereas $(x 43$ immunoreactivity is restricted to a large plaque (red) at a region of cell-to-cell contact (white arrows).

found at cellular interfaces. Instead, a diffuse increase in cytosolic Cx43 immunoreactivity was evident (Fig. 7A). Dye coupling was $0.5 \pm 0.2$, not different from that of mock-transfected clones; similarly, cellular resistance to injury was no better than mocktransfected controls (Fig. 7C). Thus, the expression of a mutant 


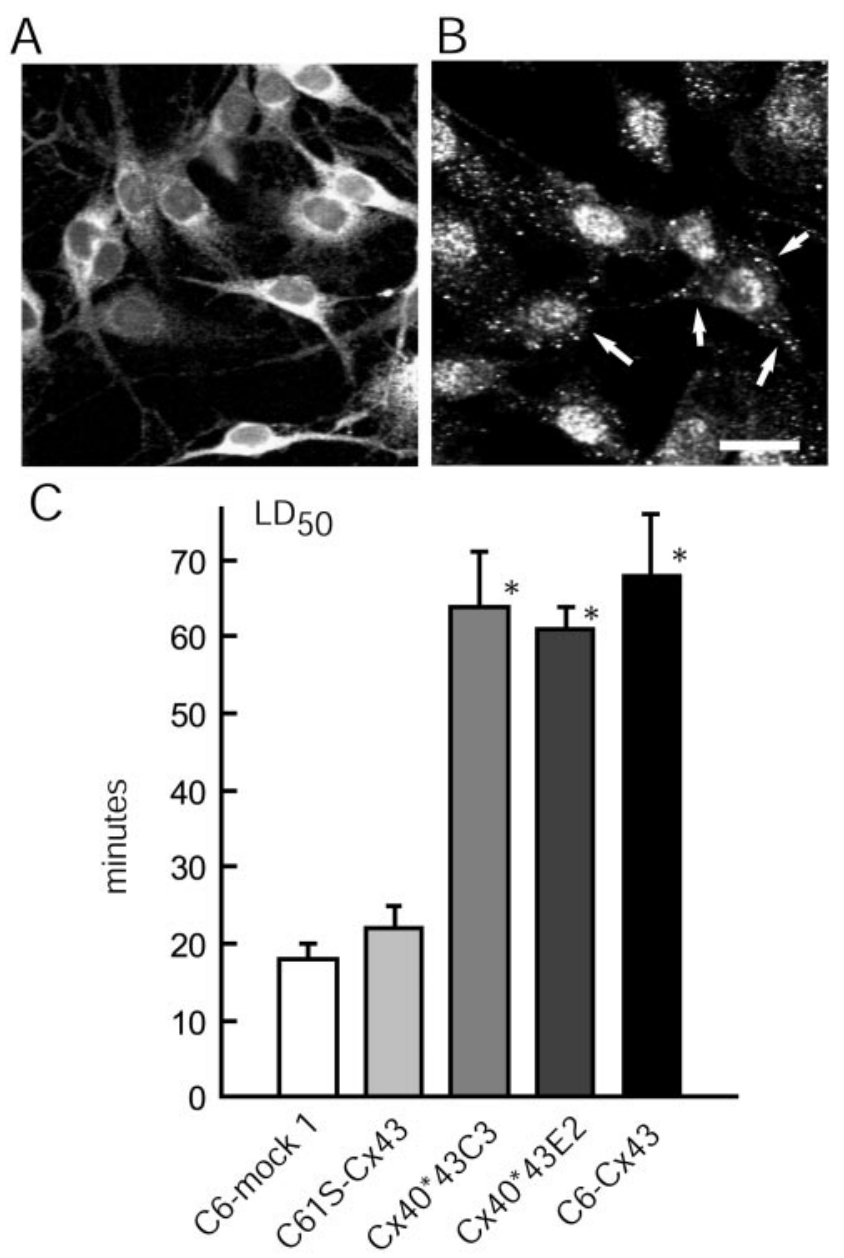

Figure 7. Plaque formation, but not functional gap junction channels, is required for $\mathrm{CX}$ mediated injury resistance. $A$, Diffuse $\mathrm{Xx} 43$ immunoreactivity in the cytosol of C 6 cells trans-

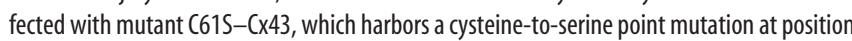
61. The C61S-Cx43 proteins do not form gap junction plaques, and correspondingly, do not increase the injury resistance. $B$, $C 6$ cells transfected with a chimeric construct, $C \times 40^{*} 43 C 3$, display immunoreactive plaques in cell membrane (arrows) and an increase in injury resistance. The expression of the $\mathrm{C} \times 40^{*} 43$ chimeras was visualized by an anti- $C \times 40$ antibody, because the Cx43 antibodies target the $C$-terminal tail, which is not present in the chimeric constructs. Scale bar: (in $B) A, B, 35 \mu \mathrm{m}$. C, Histograms summarizing the $\mathrm{LD}_{50}$ for ionophore $(40 \mu \mathrm{M})$ exposure. ${ }^{*} p<0.01$; ANOVA and post hoc Bonferroni $t$ test compared with C 6 -mock 1 cells. Error bars indicate SEM.

connexin that is not translocated to the membrane did not increase cellular tolerance to injury.

Our next question was whether gap junction function is required for connexin-mediated injury resistance or the docking of two hemichannels in the absence of channel activity is sufficient for the resistance. To this end, chimeric constructs that had been produced by swapping corresponding domains of $\mathrm{Cx} 40$ with those of $\mathrm{Cx} 43$ were expressed in C6 cells. Two of the constructs, $\mathrm{Cx} 40^{\star} 43 \mathrm{E} 2$ and $\mathrm{Cx} 40^{\star} 43 \mathrm{C} 3$, formed abundant $\mathrm{Cx} 40$ immunoreactive plaques that were nonetheless composed of nonfunctional channels in which neither dye transfer nor electrical coupling persisted (Haubrich et al., 1996; Lin et al., 2002) (Fig. 7B). Importantly, the injury resistance of C6 cells increased substantially after the expression of each of these plaque-forming yet functionally incompetent connexin chimeras: the $\mathrm{LD}_{50}$ of $\mathrm{Cx} 40^{\star} 43 \mathrm{E} 2-$ and Cx40*43C3-expressing C6 to calcium ionophore exposure was not

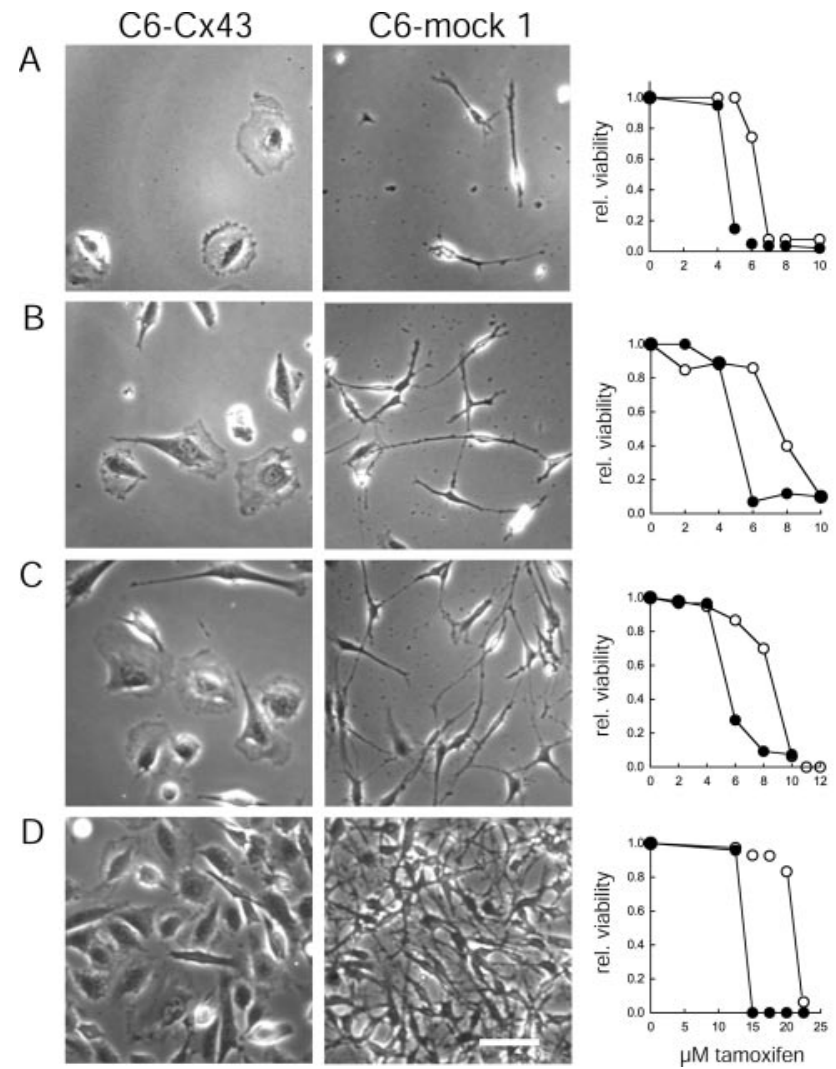

Figure 8. $\quad(6-C \times 43$ cells remain resistant to injury in the absence of gap junctions. Representative fields of $C 6-C \times 43$ (left) and 66 -mock 1 (middle) cell cultures in 24 well plates at 7000 $(A), 15,000(B), 23,000(C)$, and 115,000 (C6-Cx43) or 200,000 (C6-mock 1) (both were confluent cultures) $(D)$ cells per well. Note that at the lowest plating densities, cells rarely contact each other, thereby physically preventing the formation of gap junction channels. Scale bar, $50 \mu \mathrm{m}$. Right, Comparison of viability of $\mathrm{C} 6-\mathrm{Cx} 43(\bigcirc)$ and $\mathrm{C} 6$-mock 1 (O) cells after exposure to increasing concentrations of tamoxifen. The sensitivity to tamoxifen increases inversely with the plating density for both C6-Cx43 and C6-mock cells. C6-Cx43 cells maintain their high resistance at plating densities at which gap junction coupling is prevented by the physical separation of the cells. Data are from a representative set of experiments. Similar results have been obtained from two other independent studies.

significantly different from the highly resistant C6-Cx43 cells (Fig. 7C). Together, these results suggest that plaque formation is a critical element in connexin-dependent injury resistance, but that functional gap junction channels are not required.

High resistance of isolated $\mathrm{Cx} 43$-expressing cells

Another approach to test the role of intercellular coupling in injury resistance is to generate low-density cultures in which the lack of physical contact prevents gap junction assembly. Several plating densities were examined, and it was clear that the resistance to tamoxifen of both C6-Cx43 and C6-mock 1 cells decreased as a function of plating density in accordance with the general impression that low-density cultures are less resistant to injury (Fig. 8). When the cells were plated at or below a density of 10,000 per 24 wells, only a limited number of cells established contact with surrounding cells. Despite their inability to form gap junctions, C6-Cx43 cells still tolerated and survived higher concentrations of tamoxifen than did C6-mock cells. This observation supports the notion that the high injury resistance of $\mathrm{C} 6-\mathrm{Cx} 43$ cells is not a direct result of gap junction coupling (Fig. 8). Of note, low-density cultures were not apt to be exposed to lasalocid, because the repeated medium changes used in the injury paradigm resulted in a significant cell loss. 

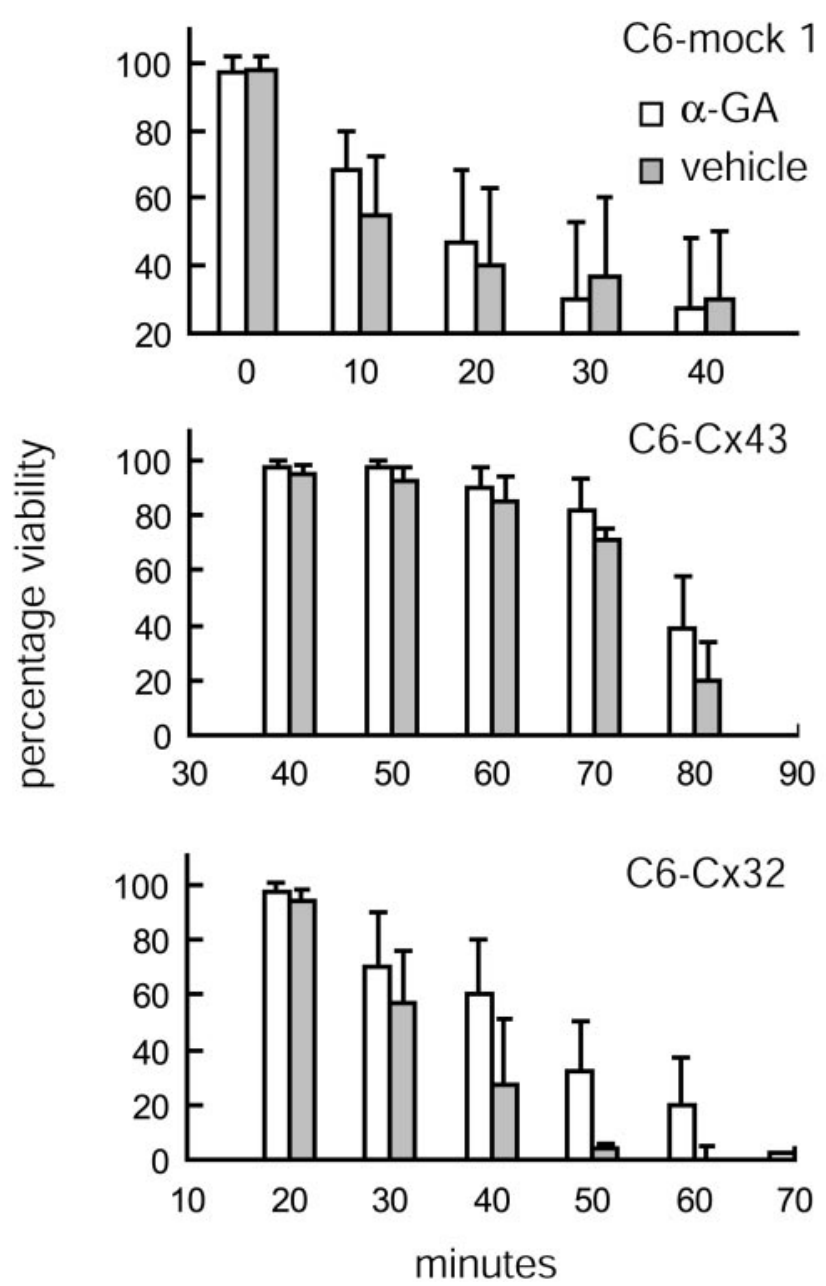

Figure 9. $\quad(x$-mediated resistance is not affected by gap junction blockage. The gap junction inhibitor $\alpha$-GA does not significantly ( $p=0.09$ for $\mathrm{LD}_{50}$ of $\mathrm{C} 6-\mathrm{C} \times 32 \pm \alpha$-GA) reduce the extent of injury after ionophore exposure. Viability (as percentage of vehicle control) is plotted as a function of increasing exposure time to lasalocid ( $40 \mu \mathrm{m})$ of $(6-$ mock $1,(6-C \times 43$, and C6-Cx32 cells. Error bars indicate SEM.

\section{Gap junction inhibitors do not decrease the resistance of C6-Cx43 cells}

To further confirm the gap junction-independent nature of $\mathrm{Cx}$ mediated resistance, we tested the effect of a relatively nontoxic gap junction inhibitor, $18 \alpha$-glycyrrhetinic acid ( $\alpha$-GA) on cellular resistance. $\alpha$-GA (50 $\mu \mathrm{M}, 24 \mathrm{hr}$ ) decreased coupling among C6-Cx43 cells by $97 \pm 4 \%$ (Fig. 1B,C) (Cotrina et al., 1998b). The treated cells appeared normal otherwise. $\alpha$-GA-treated cultures were more sensitive to calcium ionophore than vehicleexposed controls, although the difference was not significant. Similarly, C6-Cx32 exposed to $\alpha$-GA displayed an insignificant reduction in resistance to calcium ionophore compared with matching controls. The $\mathrm{LD}_{50}$ of $\mathrm{C} 6-\mathrm{Cx} 32$ cells decreased from $43 \pm 12$ to $38 \pm 9$ min when treated with $\alpha$-GA $(p=0.09)$. Because C6-mock 1 cells were insensitive to $\alpha$-GA (Fig. 9), these observations suggest that the decreased resistance of C6-Cx43 and C6-Cx32 cultures in the presence of $\alpha$-GA was linked specifically to a reduction in intercellular coupling. However, because $\alpha$-GA changed the injury threshold only marginally while efficiently reducing gap junction coupling, this finding supports and extends the notion that a functional gap junction channel plays only a minor and insignificant role in Cx-mediated injury protection.
Structural changes associated with the expression of $\mathrm{Cx}$ in part explain the increased resistance

We have noted previously that Cx expression is associated with cellular flattening and with the formation of epithelial-like sheets of polygonal cells. C6-mock and C6 wild-type cells contain only few and poorly organized stress fibers, whereas actin is typically organized in parallel arrays of stress fibers in C6-Cx43 and C6Cx32 cells (Cotrina et al., 1998C) (Fig. 10). Because cell geometry in itself is recognized as a determinant of cellular resistance (Chen et al., 1997; Dike et al., 1999; Huang and Ingber, 2000), we tested the proposition that the $\mathrm{Cx}$-induced phenotypic transformation contributed to the increased cellular resistance beyond the role of connexins in gap junction assembly. To that end, C6-Cx43 cells were raised in spheres by transferring dissociated cells to plates with nonadhesive substrate. The cells clustered within $2-4 \mathrm{hr}$ and formed large aggregates consisting of several hundred cells by 24 $\mathrm{hr}$. Figure 10 illustrates cultures fixed $24 \mathrm{hr}$ after plating and stained with Texas Red-phalloidin. Characteristically, actin organized in aggregates of both $\mathrm{C} 6-\mathrm{Cx} 43$ and C6-mock 1 cells in a rim below the plasma membrane. Phalloidin staining was somewhat weaker in C6-mock 1 cells, in accordance with our previous observations (Cotrina et al., 2000). C6-Cx43 and C6-mock 1 cells raised in spheres were considerably less resistant to injury compared with attached sister cells. $\mathrm{LD}_{50}$ decreased from $67 \pm 5$ to $40 \pm 6 \mathrm{~min}$ and from $15 \pm 3$ to $9 \pm 2 \mathrm{~min}$ of lasalocid exposure in $\mathrm{C} 6-\mathrm{Cx} 43$ and $\mathrm{C} 6-$ mock cells, respectively. Thus, the lack of substrate attachment reduced cellular resistance. However, importantly, C6-Cx43 cells remained more resistant than C6mock cells, indicating that the resistance to injury of C6-Cx43 cells was not simply a result of altered cell morphology.

Purinergic receptor antagonists reverse the resistance of $\mathbf{C x}$ expressing cells by a mechanism requiring structural changes In addition to its role in energy metabolism, ATP is a transmitter with its own set of receptors, the purinergic receptors. We have noted previously that $\mathrm{Cx}$-expressing cells release 10 - to 100 -fold more ATP than mock-transfected control cells (Cotrina et al., 1998b, 2000). Because extracellular ATP functions as a differentiation factor that mediates cellular flattening and stress fiber formation (Abbracchio et al., 1995), we tested the effect of purinergic receptor antagonists on injury resistance. Twenty-four hours of pretreatment with either suramin $(50 \mu \mathrm{M})$ or reactive blue $(50 \mu \mathrm{M})$ induced cellular compaction and loss of stress fibers, as observed previously, and resulted in a lower threshold to injury than matching vehicle-treated $\mathrm{C} 6-\mathrm{Cx} 43$ cells. $\mathrm{LD}_{50}$ decreased from $14.3 \pm 1.2 \mu \mathrm{M}$ in vehicle-treated cultures to $9.4 \pm$ 0.7 and $8.9 \pm 1.1 \mu \mathrm{M}$ in suramin- and reactive blue-exposed cultures, respectively (Fig. 11D). Because both suramin and reactive blue are characterized by a relatively unspecific mode of action, it is important that both antagonists altered the resistance of C6-mock cells only insignificantly. In contrast, if suramin and reactive blue were added immediately before the tamoxifen exposure, the injury sensitivity of either C6-Cx43 or C6-mock cells did not change significantly (data not shown). These observations indicate that purinergic receptors do not play a direct role in injury protection, but that receptor antagonists potentiate cell death indirectly by altering cellular organization to a compact and less-resistant phenotype. Of note, although cultures treated with either suramin or reactive blue exhibited a reduced number of cellular contacts, gap junction coupling was not significantly reduced (Fig. 11A-C). 
C6-C 643
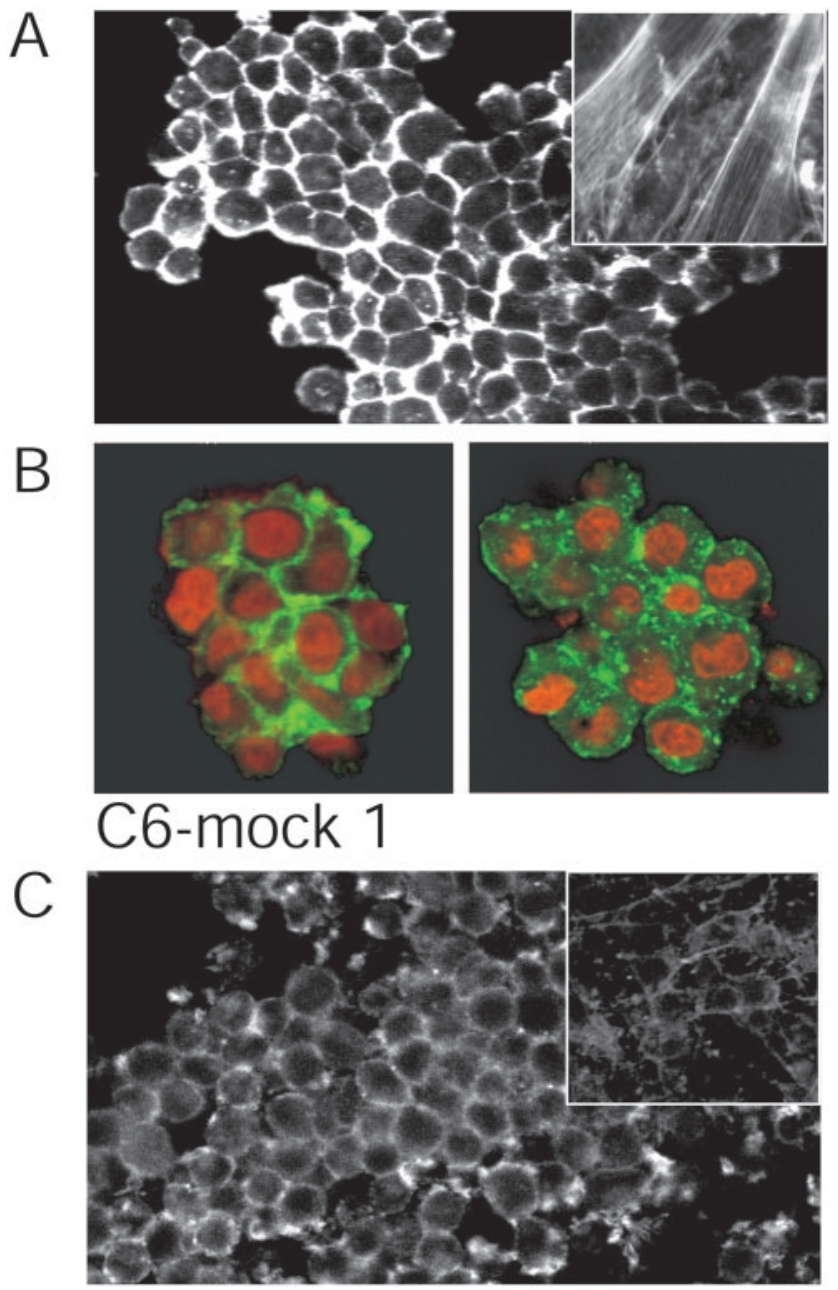

D
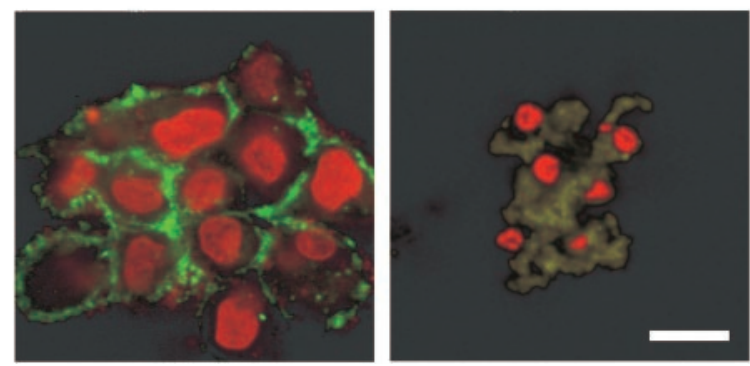

Figure 10. Cx-mediated resistance persists in suspended cells. $A$, A sphere of $C 6-C x 43$ cells that grew on a low-attachment plate stained with Texas Red-phalloidin. Actin is organized in a cortical mantle below the plasma membrane and is not in parallel arrays of stress fibers as in attached sister cells (inset). B, Spheres of C 6 - Cx43 cells exposed for $24 \mathrm{hr}$ to either vehicle (left) or $20 \mu \mathrm{m}$ tamoxifen (right). The culture was stained with phalloidin ( green) and propidium $(\mathrm{red})$. Exposure to tamoxifen does not result in killing $\mathrm{C} 6-\mathrm{Cx} 43$ cells. C, A sphere of $\mathrm{C} 6$-mock 1 cells stained with phalloidin. Actin in these cells is organized in a cortical mantle below the plasma membrane both in the sphere and in attached sister cells (inset). Note that phalloidin staining is weaker compared with $C 6-C \times 43$ cells $(A, B)$. D, Spheres of $(6$-mock 1 cells exposed for $24 \mathrm{hr}$ to either vehicle (left) or $20 \mu \mathrm{m}$ tamoxifen (right). Condensed apoptotic nuclei in the tamoxifen-exposed sphere reveal that $(6$-mock 1 cells $(D$, right) remain more sensitive to tamoxifen than $(6-C \times 43$ cells (B, right). Scale bar, $20 \mu \mathrm{m}$.

Astrocytes from Cx43 knock-out mice and wild-type astrocytes are equally resistant to ionophore

Several groups have shown previously that astrocytes from Cx43-KO mice maintain 5\% residual coupling compared with
A

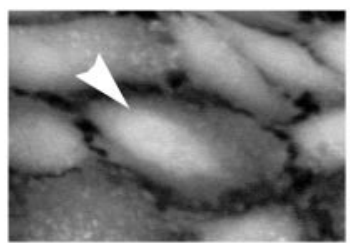

B
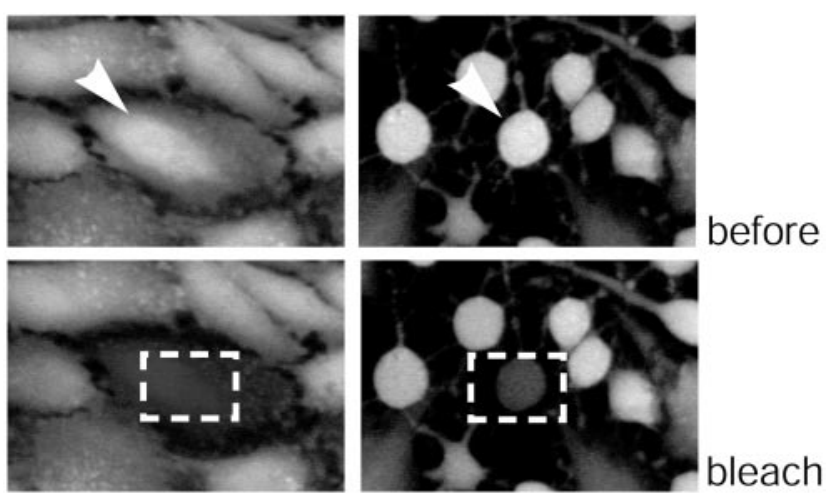

bleach
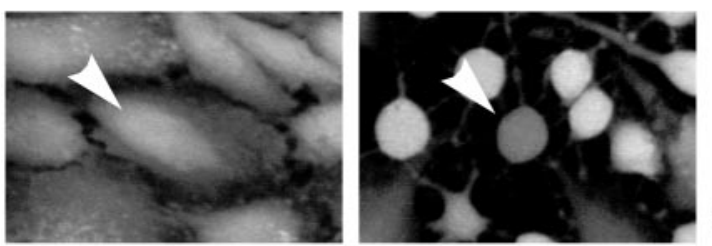

$1 \mathrm{~min}$
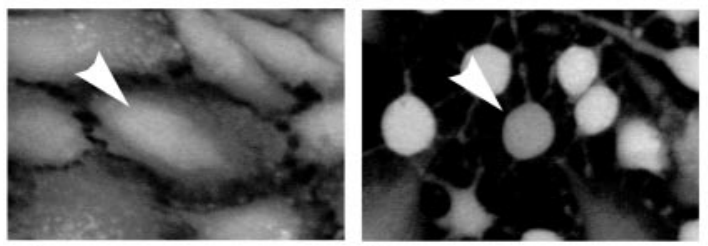

$2 \min$

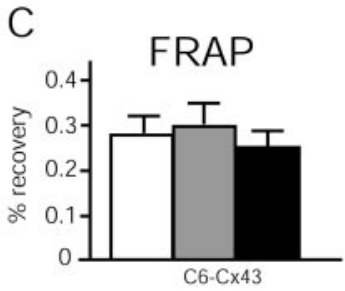

D

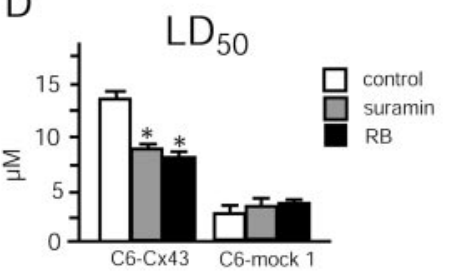

Figure 11. C6-Cx43 cells pre-exposed to purinergic receptor P2Y antagonists remain coupled by gap junctions despite compaction and retraction, but their resistance to tamoxifen is compromised. $A$, Untreated $C 6$ - $\mathrm{C} 43$ culture loaded with the gap junction-permeable fluorescence indicator CDCF. Top, A field of cells before photobleach. Bottom, A field of cells collected immediately after photobleach, or 1 and 2 min later. The rapid recovery of CDCF fluorescence indicates that the cells are well coupled by gap junctions to neighboring cells. Arrowheads indicate the cell that is subjected to photobleach. Dashed boxes indicate areas of photobleach. $B$, C6-Cx43 cells exposed to the purinergic receptor antagonist reactive blue $(50 \mu \mathrm{m})$ for $24 \mathrm{hr}$. Exposure to reactive blue does not decrease gap junction coupling, despite the reduction in cellular contact. C, Fluorescence recovery after photobleach in vehicle-, reactive blue-, and suramin-treated (50 $\mu \mathrm{m}$ each, $24 \mathrm{hr}$ ) $\mathrm{C} 6-\mathrm{C} \times 43$ cultures. $D$, Comparison of tamoxifen $\mathrm{LD}_{50}$. Reactive blue $(R B)$ and suramin ( $50 \mu \mathrm{m}$ each, $24 \mathrm{hr}$ ) significantly reduce $\mathrm{LD}_{50}$ for $\mathrm{C} 6-\mathrm{C} \times 43$ but not the $\mathrm{LD}_{50}$ for 66 -mock 1 cells. ${ }^{*} p<0.01$; Student's $t$ test.

astrocytes from matching wild-type controls, likely reflecting that astrocytes in addition to Cx43 also express low levels of Cx30, Cx40, and Cx45 (Dermietzel and Spray, 1998; Cotrina et al., 2000). The phenotypic characteristics of Cx43-KO astrocytes are indistinguishable from astrocytes prepared from wild-type littermates, despite the severe reduction in gap junction coupling (Cotrina et al., 1998c; Scemes et al., 2000). Likewise, we observed that astrocytes prepared from $\mathrm{Cx} 43-\mathrm{KO}$ mice displayed only an insignificant reduction in injury resistance (Fig. 12). The $\mathrm{LD}_{50}$ of ionophore-induced cell death was $6.4 \pm 0.6 \mathrm{~min}$ in astrocytes harvested from $\mathrm{Cx} 43-\mathrm{KO}$ mice versus $7.3 \pm 1.1 \mathrm{~min}$ in astrocytes prepared from the matching wild-type control. Thus, the loss of $\mathrm{Cx} 43$ did not significantly reduce injury resistance. Activation of compensatory mechanisms during development is common in 


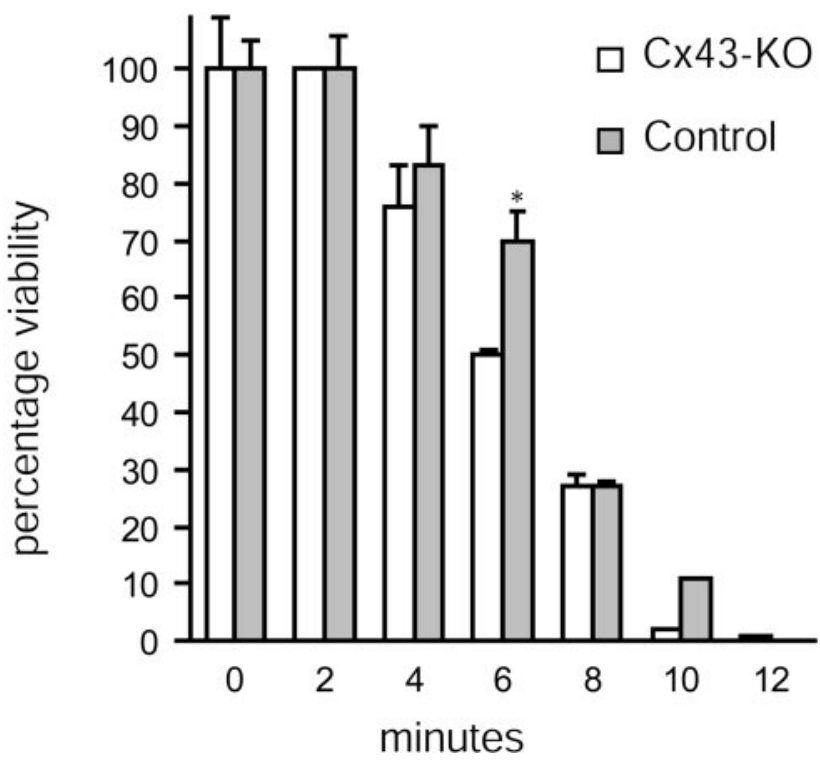

Figure 12. No difference in ionophore sensitivity between wild-type and Cx43-K0 astrocytes. Confluent cultures were treated with $40 \mu \mathrm{m}$ lasalocid for the times indicated. Viability was evaluated by alamar blue assay and expressed as a percentage of vehicle control. The $L_{50}$ for wild-type versus C $43-\mathrm{KO}$ astrocytes is not significantly different. Error bars indicate SEM.

studies of $\mathrm{KO}$ mice, and the fact that the phenotype (e.g., cell morphology and calcium wave propagation) of astrocytes from $\mathrm{Cx} 43-\mathrm{KO}$ was indistinguishable from that of the wild-type suggests that compensatory mechanisms are indeed activated. Because the expression of other members of the Cx family is not upregulated and gap junction coupling is reduced in astrocytic cultures prepared from $\mathrm{Cx} 43-\mathrm{KO}$ mice, this set of observations adds additional support to the conclusion that gap junction channel formation plays a minor role in cellular resistance to injury.

\section{Impact of $\mathrm{Cx}$ expression on calcium regulation}

To determine whether changes in cytosolic calcium concentration, $\left[\mathrm{Ca}^{2+}\right]_{\mathrm{i}}$, during injury predict the extent of cell death, we measured $\left[\mathrm{Ca}^{2+}\right]_{\mathrm{i}}$ during and after exposure to lasalocid $(40 \mu \mathrm{M})$ in fura-2-loaded cultures (Lin et al., 1998). Resting $\left[\mathrm{Ca}^{2+}\right]_{\mathrm{i}}$ was in the range of $80-120 \mathrm{~nm}$ in all clones studied, including $\mathrm{C} 6-$ mock 1, C6-Cx43, and C6-Cx32 cells. When exposed to the calcium ionophore, $\mathrm{C} 6-\mathrm{Cx} 43$ cells displayed an initial increase in $\left[\mathrm{Ca}^{2+}\right]_{\mathrm{i}}$, which peaked at $600 \mathrm{~nm}$, followed by a slow normalization of $\left[\mathrm{Ca}^{2+}\right]_{\mathrm{i}} \sim 10 \mathrm{~min}$ later, and $\left[\mathrm{Ca}^{2+}\right]_{\mathrm{i}}$ returned to $200-300$ $\mathrm{nm}$ and remained at this level during the rest of the experiment. C6-Cx32 cells responded to the ionophore in a similar manner, as did C6-Cx43 cells (data not shown). In contrast, the ionophore-induced $\left[\mathrm{Ca}^{2+}\right]_{\mathrm{i}}$ elevation peaked at $\sim 1000 \mathrm{nM}$ in C6-mock 1 cells; the initial attempt to restore $\left[\mathrm{Ca}^{2+}\right]_{\mathrm{i}}$ levels was followed by a delayed and irreversible increase in $\left[\mathrm{Ca}^{2+}\right]_{\mathrm{i}}$. This second increase in $\left[\mathrm{Ca}^{2+}\right]_{\mathrm{i}}$ rose slowly and did not normalize: After ionophore washout, $\left[\mathrm{Ca}^{2+}\right]_{\mathrm{i}}$ levels decreased but remained elevated in the majority of the C6-mock 1 cells. To compare the different cellular $\left[\mathrm{Ca}^{2+}\right]_{\mathrm{i}}$ responses directly, we exposed cocultures of C6-Cx43 and C6-mock 1 cells to lasalocid. Figure 13 illustrates that the cell-specific changes in $\left[\mathrm{Ca}^{2+}\right]_{i}$ were maintained in cocultures, and that $\mathrm{C} 6-\mathrm{Cx} 43$ cells displayed minor and shorter-lasting increments in $\left[\mathrm{Ca}^{2+}\right]_{\mathrm{i}}$ compared with $\mathrm{C} 6-$ mock 1 cells.

To further compare $\left[\mathrm{Ca}^{2+}\right]_{\mathrm{i}}$ responses in $\mathrm{Cx}$-expressing ver- sus $\mathrm{Cx}$-deficient cells over time, we integrated $\left[\mathrm{Ca}^{2+}\right]_{\mathrm{i}}$ increments above resting levels over the course of the experiment ( 60 $\mathrm{min})$. The integral of $\left[\mathrm{Ca}^{2+}\right]_{\mathrm{i}}$ increase was significantly higher in $\mathrm{Cx}$-deficient compared with $\mathrm{Cx}$-expressing cells. The $\left[\mathrm{Ca}^{2+}\right]_{\mathrm{i}}$ integral averaged $12 \pm 0.8$ and $15 \pm 1 \mu \mathrm{M}$ in C6-Cx43 and C6Cx32 cells, respectively, compared with $40 \pm 6 \mu \mathrm{M}$ in C6-mock 1 cells $(n=10 ; p<0.01)$. Thus, $\left[\mathrm{Ca}^{2+}\right]_{\mathrm{i}}$ increased significantly less over time in the Cx-expressing clones compared with the mocktransfected clones. In other words, $\mathrm{Cx}$-expressing cells were able to restore and maintain $\left[\mathrm{Ca}^{2+}\right]_{\mathrm{i}}$ homeostasis in the presence of ionophore, whereas C6-mock 1 cells failed to do so.

\section{DISCUSSION}

The new observation in this report is that the expression of Cxs, the integral proteins of gap junctions, is associated with an increased resistance of a variety of cells to most but not all types of injury. The magnitude of the resistance provided by several members of the Cx family was comparable with the protection afforded by the widely known proto-oncogene Bcl2. Blockage of $\mathrm{Cx} 43$ by its dominant-negative mutants suppressed cellular resistance to tamoxifen. Surprisingly, gap junction coupling per se appeared to play a minor role in injury protection. Several lines of observations supported the notion that $\mathrm{Cx}$-mediated injury resistance did not require the physical formation of gap junction channels. First, Cx-expressing cells retained their resistance in low-density cultures with few cell contacts. Second, pharmacological inhibition of gap junction channels only insignificantly reduced the injury resistance of $\mathrm{Cx}$-expressing clones. Third, the expression of two Cx constructs that failed to establish functional gap junctions efficiently protected the cells against injury. The mechanism by which Cx proteins enhance cell resistance was not clearly defined, but cell flattening and stress fiber assembly contributed to injury resistance in Cx-expressing cells (Chen et al., 1997; Dike et al., 1999; Cotrina et al., 2000; Huang and Ingber, 2000).

In this study we compared $\mathrm{Cx}$-mediated injury resistance with the effects of $\mathrm{Bcl} 2$ expression. $B c l 2$ was first found to permit the survival of cytokine-dependent hematopoietic cells (Vaux et al., 1988), and its anti-apoptotic action was later verified in several other cell types (Chao et al., 1995). Bcl2 is located primarily on the cytoplasmic face of the mitochondrial outer membrane (Hockenbery et al., 1990), where it inhibits the release of cytochrome $c$ to cytosol (Kluck et al., 1997; Yang et al., 1997; Shimizu et al., 1999). In addition, $B c l 2$ has a variety of other functions (Green and Reed, 1998). Several mitochondrial events have been linked to $B c l 2$, including regulation of the ATPase mitochondrial proton pump, increases in mitochondrial $\mathrm{Ca}^{2+}$ buffering capacity, and prevention of mitochondrial permeability transition (Adams and Cory, 1998; Green and Reed, 1998). It is of interest to note that $B c l 2$, like several members of the Cx family, forms channels in lipid bilayers and modulates cell-cycle progression and proliferation (Chao and Korsmeyer, 1998). In addition to their antiapoptotic actions, both connexins and $\mathrm{Bcl} 2$ prevent necrotic cell death (Zhong et al., 1993; Kane et al., 1995; Myers et al., 1995).

For decades it was assumed that cells uncouple during the process of death. We recently challenged this view by demonstrating functional coupling among ischemic dying astrocytes both in vivo and in vitro (Cotrina et al., 1998a). Although coupling decreases, astrocytes remain interconnected during the process of ischemic cell death. In fact, subsequent experiments have documented that gap junctions can propagate or amplify focal injury to include otherwise viable neighboring cells, socalled bystander death. Bystander death has been observed in a 

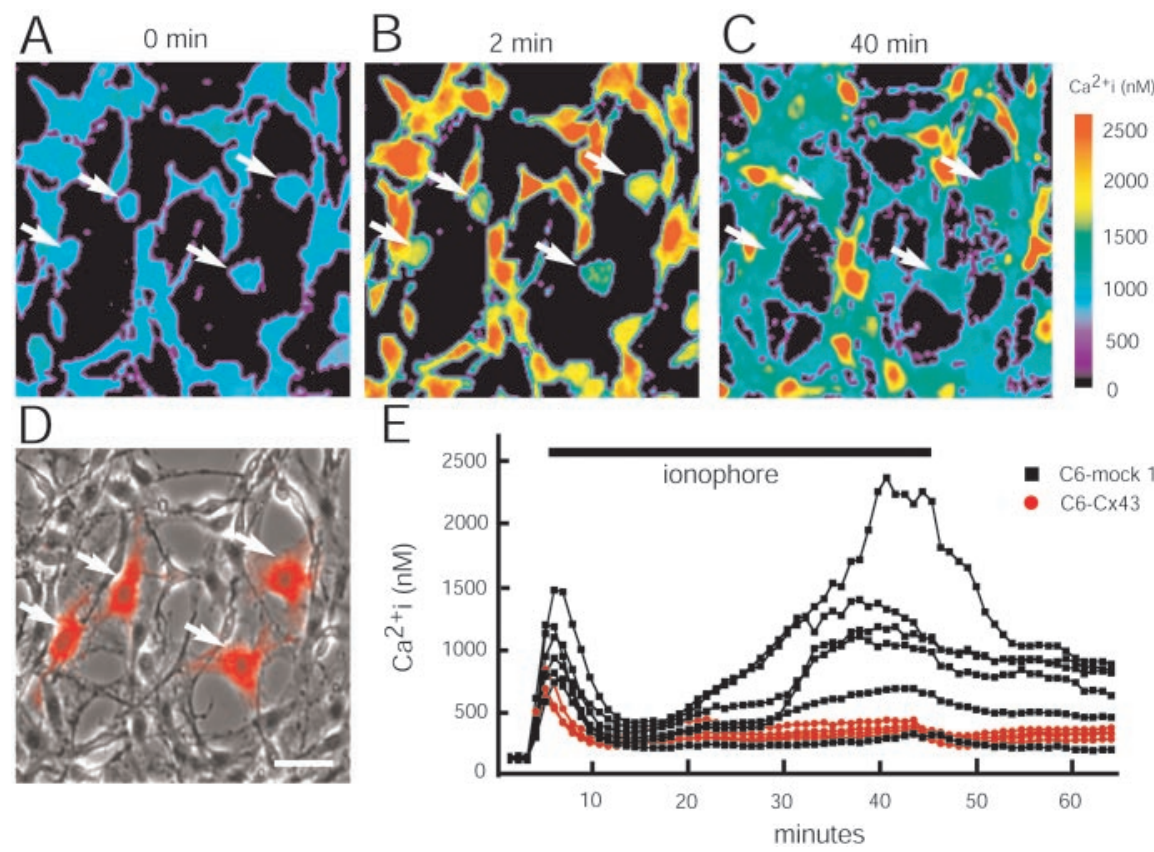

Figure 13. Ionophore-induced increases in cytosolic $\left[\mathrm{Ca}^{2+}\right]_{\text {; }}$ are suppressed by $C x$ expression. $A$, Resting $\left[\mathrm{Ca}^{2+}\right]_{\mathrm{i}}$ levels in a mixed culture of $\mathrm{C} 6-\mathrm{CX} 43$ (white arrows) and $\left(6\right.$-mock 1 cells loaded with the calcium indicator fura-2. $B$, Peak $\left[\mathrm{Ca}^{2+}\right]_{\mathrm{i}}$ increments during exposure to the calcium ionophore lasalocid ( $40 \mu \mathrm{m})$. Note the lower amplitude of $\left[\mathrm{Ca}^{2+}\right]_{\mathrm{i}}$ increments in $\mathrm{C} 6-\mathrm{C} \times 43$ cells (white arrows) compared with $\left(6-\right.$-mock 1 cells. C, After 40 min of ionophore exposure, $\left[\mathrm{Ca}^{2+}\right]_{\mathrm{i}}$ in all four $\mathrm{C6}-\mathrm{C} \times 43$ cells had normalized to a level somewhat higher than resting $\left[\mathrm{Ca}^{2+}\right]_{\mathrm{i}}$, whereas $\left[\mathrm{Ca}^{2+}\right]_{\mathrm{i}}$ remained elevated in the majority of $(6$-mock 1 cells. D, Phase contrast micrograph of the same field. The $C 6-C \times 43$ cells were prelabeled with the cell tracker CMTMR. The CMTMR labeling was digitally superimposed to visualize $66-\mathrm{C} \times 43$ cells. Note the flat morphology of $\mathrm{C6}-\mathrm{C} \times 43$ cells compared with the elongated C6-mock 1 cells that typically exhibit less cellular contact. $E_{,}\left[\mathrm{Ca}^{2+}\right]_{\mathrm{i}}$ as a function of time in the cultures shown in $A-C$. Peak $\left[\mathrm{Ca}^{2+}\right]_{\mathrm{i}}$ increments in $\mathrm{C}_{6}-\mathrm{Cx}_{43}$ cells duringionophore exposure are lowerthan those in surrounding (6-mockcells (left; $p<0.001$; Student'st test), normalizefaster, and do not show a delayed secondary increase in calcium. Scale bar: (in D) $A-D, 50 \mu \mathrm{m}$.

variety of settings, including focal experimental ischemia (Rawanduzy et al., 1997), in cultured cells (Lin et al., 1998), after the traumatic injury of cultured hippocampal slices (Frantseva et al., 2002), and in a model of transient global ischemia (Rami et al., 2001). In essence, the gap junction can increase local injury by expanding death to neighboring cells. However, it is important to note that the $\mathrm{Cx}$-mediated injury resistance observed in this study does not contradict the existence of bystander death (Lin et al., 1998). The two phenomena, bystander death and $\mathrm{Cx}$-mediated injury resistance, differ fundamentally. Bystander death is triggered by gap junction-mediated diffusion of the intracellular messenger and is attenuated by gap junction inhibitors (Rawanduzy et al., 1997). In contrast, Cxmediated injury resistance does not require gap junction formation and is insensitive to uncoupling agents (Fig. 9). The ability to distinguish clearly between bystander death and Cxmediated injury resistance in this study may aid future analyses of the role of Cxs in cell injury.

The mechanism of Cx-mediated injury protection is not clearly defined, but there is no doubt that a monolayer of cells fights stressful conditions more efficiently than isolated cells. It is possible that sharing a common pool of metabolites and intracellular messengers improves survival. Our data support this conclusion by demonstrating that cellular resistance decreased in proportion with plating density (Fig. 8). The surprising and less intuitive observation is that $\mathrm{Cx}$-mediated resistance for the most part was not a result of gap junction channel formation. Physically isolated Cx-expressing cells remained highly resistant, despite their inability to form gap junctions. Another observation was that the expression of nonfunctional $\mathrm{Cx}$ chimeras gave rise to a highly resistant but poorly coupled cellular phenotype. Additional support for a relatively minor role of gap junction coupling in injury protection derives from the inability of gap junction inhibitors to reduce cellular resistance. We speculate that $\mathrm{Cx}$-induced cellular flattening and stress fiber formation play a significant protective role, but that other factors, in particular a more efficient apparatus for calcium homeostasis, are important. This conclusion is based on the notion that $\mathrm{Cx}$-expressing cells raised in spheres on low-attachment plates remained resistant compared with $\mathrm{Cx}$ deficient sister cells, although these culture conditions prevented stress fiber formation. In this regard, $\mathrm{Cx}$ proteins have been implicated in several gap junctionindependent processes. For example, $\mathrm{Cx}$ expression potentiates ATP release (and long-distance calcium waves), decreases cellular proliferation (Huang et al., 1998), and regulates the invasive capacity of malignant glioma cells by gap junctionindependent pathways (Lin et al., 2002). Thus, yet-to-be-determined properties of hemichannels may well be crucial to the survival of Cx-expressing cells. In fact, Cx43 hemichannels have been shown recently to play a role in the anti-apoptotic actions of bisphosphonates (Plotkin et al., 2002). Bisphosphonates are stable analogs of pyrophosphates, which prevent osteocyte and osteoblast apoptosis induced by glucocorticoids. Bisphosphonates are widely used in the treatment of bone diseases and require activation of the extracellular signal-regulated kinases (ERKs). Plotkin et al. (2002) proposed that bisphosphonates induced openings of Cx43 hemichannels, resulting in a conformational change of $\mathrm{Cx} 43$, which through a sequence of steps culminated in ERK phosphorylation and cell survival. The difference in the expression of glucocorticoid receptors and thereby in intracellular signal transduction varies among different cell types and may explain why Cx43 failed to protect against dexamethasone-induced death in C6 cells. Nevertheless, it is intriguing that Cx43 hemichannels have been shown to transduce survival signals in response to extracellular cues in another cell type. As for the unaltered sensitivity of astrocytes prepared from $\mathrm{Cx} 43-\mathrm{KO}$ mice, hemichannels assembled by other members of the $\mathrm{Cx}$ family may contribute to the retaining of astrocytic resistance, because primary astrocytes in cultures express an abundance of functional Cx43 hemichannels (Hofer and Dermietzel, 1998). Unopposed Cx43 hemichannels are induced to open during chemical ischemia (Contreras et al., 2002). Some of these hemichannel properties may be crucial to the survival of $\mathrm{Cx}$-expressing cells in suspension.

Additional studies are required to establish the mechanism underlying $\mathrm{Cx}$-dependent injury resistance, but it should not be surprising that a protein known to participate in essentially all of the vital cellular processes, including cell-to-cell signaling, proliferation, differentiation, and anaplastic transformation, also has a significant impact on the process of cell death. 


\section{References}

Abbracchio MP, Ceruti S, Langfelder R, Cattabeni F, Saffrey MJ, Burnstock G (1995) Effects of ATP analogues and basic fibroblast growth factor on astroglial cell differentiation in primary cultures of rat striatum. Int J Dev Neurosci 13:685-693.

Abrams CK, Bennett MV, Verselis VK, Bargiello TA (2002) Voltage opens unopposed gap junction hemichannels formed by a connexin 32 mutant associated with X-linked Charcot-Marie-Tooth disease. Proc Natl Acad Sci USA 99:3980-3984.

Adams JM, Cory S (1998) The Bcl-2 protein family: arbiters of cell survival. Science 281:1322-1326.

Andrade-Rozental AF, Rozental R, Hopperstad MG, Wu JK, Vrionis FD, Spray DC (2000) Gap junctions: the "kiss of death" and the "kiss of life". Brain Res Brain Res Rev 32:308-315.

Arcuino G, Lin JH, Takano T, Liu C, Jiang L, Gao Q, Kang J, Nedergaard M (2002) Intercellular calcium signaling mediated by point-source burst release of ATP. Proc Natl Acad Sci USA 99:9840-9845.

Benda P, Lightbody J, Sato G, Levine L, Sweet W (1968) Differentiated rat glial cell strain in tissue culture. Science 161:370-371.

Bennett MV, Zheng X, Sogin ML (1994) The connexins and their family tree. Soc Gen Physiol Ser 49:223-233.

Billecke CA, Ljungman ME, McKay BC, Rehemtulla A, Taneja N, Ethier SP (2002) Lack of functional $\mathrm{pRb}$ results in attenuated recovery of mRNA synthesis and increased apoptosis following UV radiation in human breast cancer cells. Oncogene 21:4481-4489.

Blanc EM, Bruce-Keller AJ, Mattson MP (1998) Astrocytic gap junctional communication decreases neuronal vulnerability to oxidative stressinduced disruption of $\mathrm{Ca}^{2+}$ homeostasis and cell death. J Neurochem 70:958-970.

Brismar T (1995) Physiology of transformed glial cells. Glia 15:231-243.

Bruzzone S, Guida L, Zocchi E, Franco L, De Flora A (2001) Connexin 43 hemichannels mediate $\mathrm{Ca}^{2+}$-regulated transmembrane $\mathrm{NAD}^{+}$fluxes in intact cells. FASEB J 15:10-12.

Carystinos GD, Katabi MM, Laird DW, Galipeau J, Chan H, Alaoui-Jamali MA, Batist G (1999) Cyclic-AMP induction of gap junctional intercellular communication increases bystander effect in suicide gene therapy. Clin Cancer Res 5:61-68.

Chao DT, Korsmeyer SJ (1998) BCL-2 family: regulators of cell death. Annu Rev Immunol 16:395-419.

Chao DT, Linette GP, Boise LH, White LS, Thompson CB, Korsmeyer SJ (1995) Bcl-XL and Bcl-2 repress a common pathway of cell death. J Exp Med 182:821-828.

Chen CS, Mrksich M, Huang S, Whitesides GM, Ingber DE (1997) Geometric control of cell life and death. Science 276:1425-1428.

Contreras JE, Sanchez HA, Eugenin EA, Speidel D, Theis M, Willecke K, Bukauskas FF, Bennett MV, Saez JC (2002) Metabolic inhibition induces opening of unopposed connexin 43 gap junction hemichannels and reduces gap junctional communication in cortical astrocytes in culture. Proc Natl Acad Sci USA 99:495-500.

Cotrina M, Kang J, Lin J, Bueno E, Liu Y, Hansen T, Nedergaard M (1998a) Astrocytic gap junctions remain open during ischemic conditions. J Neurosci 18:2520-2537.

Cotrina M, Lin JH-L, Alves-Rodrigues A, Liu S, Li J, Azmi-Ghadimi H, Kang J, Naus CCG, Nedergaard M (1998b) Connexins regulate calcium signaling by controlling ATP release. Proc Natl Acad Sci USA 95:15735-15740.

Cotrina M, Lin JH-L, Nedergaard M (1998c) Cytoskeletal assembly and ATP release regulate astrocytic calcium signaling. J Neurosci 18:8794-8804.

Cotrina ML, Lin JH, Lopez-Garcia JC, Naus CC, Nedergaard M (2000) ATP-mediated glia signaling. J Neurosci 20:2835-2844.

Dermietzel R, Spray D (1998) From neuro-glue ("nervenkitt") to glia: a prologue. Glia 24:1-7.

De Sousa PA, Juneja SC, Caveney S, Houghton FD, Davies TC, Reaume AG, Rossant J, Kidder GM (1997) Normal development of preimplantation mouse embryos deficient in gap junctional coupling. J Cell Sci 110:1751-1758.

Dike LE, Chen CS, Mrksich M, Tien J, Whitesides GM, Ingber DE (1999) Geometric control of switching between growth, apoptosis, and differentiation during angiogenesis using micropatterned substrates. In Vitro Cell Dev Biol Anim 35:441-448.

Elfgang C, Eckert R, Lichtenberg-Frate H, Lichtenberg-FrateB, Traub O, Klein RA, Hulser DF, Willecke K (1995) Specific permeability and selec- tive formation of gap junction channels in connexin-transfected HeLa cells. J Cell Biol 129:805-817.

Evans WH, Martin PE (2002) Gap junctions: structure and function. Mol Membr Biol 19:121-136.

Farinelli SE, Greene LA (1996) Cell cycle blockers mimosine, ciclopirox, and deferoxamine prevent the death of PC12 cells and postmitotic sympathetic neurons after removal of trophic support. J Neurosci 16:1150-1162.

Frantseva MV, Kokarovtseva L, Naus CG, Carlen PL, MacFabe D, Perez Velazquez JL (2002) Specific gap junctions enhance the neuronal vulnerability to brain traumatic injury. J Neurosci 22:644-653.

Goldberg GS, Bechberger JF, Naus CC (1995) A pre-loading method of evaluating gap junctional communication by fluorescent dye transfer. Biotechniques 18:490-497.

Goldberg GS, Bechberger JF, Tajima Y, Merritt M, Omori Y, Gawinowicz MA, Narayanan R, Tan Y, Sanai Y, Yamasaki H, Naus CC, Tsuda H, Nicholson BJ (2000) Connexin43 suppresses MFG-E8 while inducing contact growth inhibition of glioma cells. Cancer Res 60:6018-6026.

Green DR, Reed JC (1998) Mitochondria and apoptosis. Science 281:13091312.

Grueterich M, Espana E, Tseng SC (2002) Connexin 43 expression and proliferation of human limbal epithelium on intact and denuded amniotic membrane. Invest Ophthalmol Vis Sci 43:63-71.

Hardy S, Kitamura M, Harris-Stansil T, Dai Y, Phipps ML (1997) Construction of adenovirus vectors through Cre-lox recombination. J Virol 71:1842-1849.

Haubrich S, Schwarz HJ, Bukauskas F, Lichtenberg-Frate H, Traub O, Weingart R, Willecke K (1996) Incompatibility of connexin 40 and 43 Hemichannels in gap junctions between mammalian cells is determined by intracellular domains. Mol Biol Cell 7:1995-2006.

Ho SN, Hunt HD, Horton RM, Pullen JK, Pease LR (1989) Site-directed mutagenesis by overlap extension using the polymerase chain reaction. Gene 77:51-59.

Hockenbery D, Nunez G, Milliman C, Schreiber RD, Korsmeyer SJ (1990) $\mathrm{Bcl}-2$ is an inner mitochondrial membrane protein that blocks programmed cell death. Nature 348:334-336.

Hofer A, Dermietzel R (1998) Visualization and functional blocking of gap junction hemichannels (connexons) with antibodies against external loop domains in astrocytes. Glia 24:141-154.

Huang R, Fan Y, Hossain MZ, Peng A, Zeng ZL, Boynton AL (1998) Reversion of the neoplastic phenotype of human glioblastoma cells by connexin 43 (cx43). Cancer Res 58:5089-5096.

Huang R, Lin Y, Wang CC, Gano J, Lin B, Shi Q, Boynton A, Burke J, Huang RP (2002) Connexin 43 suppresses human glioblastoma cell growth by down-regulation of monocyte chemotactic protein 1 , as discovered using protein array technology. Cancer Res 62:2806-2812.

Huang S, Ingber DE (2000) Shape-dependent control of cell growth, differentiation, and apoptosis: switching between attractors in cell regulatory networks. Exp Cell Res 261:91-103.

Kabir J, Lobo M, Zachary I (2002) Staurosporine induces endothelial cell apoptosis via focal adhesion kinase dephosphorylation and focal adhesion disassembly independent of focal adhesion kinase proteolysis. Biochem J 367:145-155.

Kane DJ, Ord T, Anton R, Bredesen DE (1995) Expression of Bcl-2 inhibits necrotic neural cell death. J Neurosci Res 40:269-275.

Kluck RM, Bossy-Wetzel E, Green DR, Newmeyer DD (1997) The release of cytochrome $\mathrm{c}$ from mitochondria: a primary site for Bcl-2 regulation of apoptosis. Science 275:1132-1136.

Krutovskikh VA, Piccoli C, Yamasaki H (2002) Gap junction intercellular communication propagates cell death in cancerous cells. Oncogene 21:1989-1999.

Kumar N, Gilula N (1996) The gap junction communication channel. Cell 84:381-388.

Levin M (2002) Isolation and community: a review of the role of gap-junctional communication in embryonic patterning. J Membr Biol 185:177-192.

Lin JH-C, Weigel H, Cotrina M, Liu Cotrina, Bueno E, Hansen A, Hansen T, Nedergaard M (1998) Gap-junction-mediated propagation and amplification of cell injury. Nat Neurosci 1:494-500.

Lin JH, Takano T, Cotrina ML, Arcuino G, Kang J, Liu S, Gao Q, Jiang L, Li F, Lichtenberg-Frate H, Haubrich S, Willecke K, Goldman SA, Nedergaard M (2002) Connexin 43 enhances the adhesivity and mediates the invasion of malignant glioma cells. J Neurosci 22:4302-4311. 
Meda P, Pepper MS, Traub O, Willecke K, Gros D, Beyer E, Nicholson B, Paul D, Orci L (1993) Differential expression of gap junction connexins in endocrine and exocrine glands. Endocrinology 133:2371-2378.

Mesnil M, Piccoli C, Tiraby G, Willecke K, Yamasaki H (1996) Bystander killing of cancer cells by herpes simplex virus thymidine kinase gene is mediated by connexins. Proc Natl Acad Sci USA 93:1831-1835.

Moorby C, Patel M (2001) Dual functions for connexins: Cx43 regulates growth independently of gap junction formation. Exp Cell Res 271:238-248.

Myers KM, Fiskum G, Liu Y, Simmens SJ, Bredesen DE, Murphy AN (1995) Bcl-2 protects neural cells from cyanide/aglycemia-induced lipid oxidation, mitochondrial injury, and loss of viability. J Neurochem 65:2432-2440.

Nedergaard M (1994) Direct signaling from astrocytes to neurons in cultures of mammalian brain cells. Science 263:1768-1771.

Oguro K, Jover T, Tanaka H, Lin Y, Kojima T, Oguro N, Grooms SY, Bennett MV, Zukin RS (2001) Global ischemia-induced increases in the gap junctional proteins connexin $32(\mathrm{Cx} 32)$ and $\mathrm{Cx} 36$ in hippocampus and enhanced vulnerability of Cx32 knock-out mice. J Neurosci 21:7534-7542.

Omori Y, Yamasaki H (1998) Mutated connexin43 proteins inhibit rat glioma cell growth suppression mediated by wild-type connexin 43 in a dominant-negative manner. Int J Cancer 78:446-453.

Oyamada Y, Zhou W, Oyamada H, Takamatsu T, Oyamada M (2002) Dominant-negative connexin43-EGFP inhibits calcium-transient synchronization of primary neonatal rat cardiomyocytes. Exp Cell Res 273:85-94.

Plotkin LI, Manolagas SC, Bellido T (2002) Transduction of cell survival signals by connexin-43 hemichannels. J Biol Chem 277:8648 - 8657.

Qin H, Shao Q, Curtis H, Galipeau J, Belliveau DJ, Wang T, Alaoui-Jamali MA, Laird DW (2002) Retroviral delivery of connexin genes to human breast tumor cells inhibits in vivo tumor growth by a mechanism that is independent of significant gap junctional intercellular communication. J Biol Chem 277:29132-29138.

Rabkin SW, Kong JY (2002) Discordance between the effect of modulators of calcium on staurosporine-induced apoptosis and staurosporineinduced actin degradation. Cell Biol Int 26:433-440.

Rami A, Volkmann T, Winckler J (2001) Effective reduction of neuronal death by inhibiting gap junctional intercellular communication in a rodent model of global transient cerebral ischemia. Exp Neurol 170:297-304.

Rawanduzy A, Hansen A, Hansen TW, Nedergaard M (1997) Effective re- duction of infarct volume by gap junction blockade in a rodent model of stroke. J Neurosurg 87:916-920.

Reed JC, Miyashita T, Takayama S, Wang HG, Sato T, Krajewski S, AimeSempe C, Bodrug S, Kitada S, Hanada M (1996) BCL-2 family proteins: regulators of cell death involved in the pathogenesis of cancer and resistance to therapy. J Cell Biochem 60:23-32.

Scemes E, Suadicani SO, Spray DC (2000) Intercellular communication in spinal cord astrocytes: fine tuning between gap junctions and P2 nucleotide receptors in calcium wave propagation. J Neurosci 20:1435-1445.

Shimizu S, Narita M, Tsujimoto Y (1999) Bcl-2 family proteins regulate the release of apoptogenic cytochrome $\mathrm{c}$ by the mitochondrial channel VDAC. Science 399:483-487.

Simard M, Couldwell W, Zhang W, Song H, Liu S, Cotrina M, Goldman S, Nedergaard M (1999) Glucocorticoids: potent modulators of astrocytic calcium signaling. Glia 28:1-12.

Takayama S, Sato T, Krajewski S, Kochel K, Irie S, Millan JA, Reed JC (1995) Cloning and functional analysis of BAG-1: a novel Bcl-2-binding protein with anti-cell death activity. Cell 80:279-284.

Traub O, Eckert R, Lichtenberg-Frate H, Elfgang C, Bastide B, Scheidtmann KH, Hulser DF, Willecke K (1994) Immunochemical and electrophysiological characterization of murine connexin 40 and -43 in mouse tissues and transfected human cells. Eur J Cell Biol 64:101-112.

Vaux DL, Cory S, Adams JM (1988) Bcl-2 gene promotes haemopoietic cell survival and cooperates with c-myc to immortalize pre-B cells. Nature 335:440-442.

Yang J, Liu X, Bhalla K, Kim CN, Ibrado AM, Cai J, Peng TI, Jones DP, Wang X (1997) Prevention of apoptosis by Bcl-2: release of cytochrome c from mitochondria blocked. Science 275:1129-1132.

Zeng J, Fournier P, Schirrmacher V (2002) Induction of interferon- $\alpha$ and tumor necrosis factor-related apoptosis-inducing ligand in human blood mononuclear cells by hemagglutinin-neuraminidase but not $\mathrm{F}$ protein of Newcastle disease virus. Virology 297:19-30.

Zhang W, Couldwell WT, Song H, Takano T, Lin JH, Nedergaard M (2000) Tamoxifen-induced enhancement of calcium signaling in glioma and MCF-7 breast cancer cells. Cancer Res 60:5395-5400.

Zhong LT, Sarafian T, Kane DJ, Charles AC, Mah SP, Edwards RH, Bredesen DE (1993) Bcl-2 inhibits death of central neural cells induced by multiple agents. Proc Natl Acad Sci USA 90:4533-4537. 